\title{
Molecules Isolated from Mexican Hypoglycemic Plants: A Review
}

\author{
Sonia Marlen Escandón-Rivera ${ }^{1}$ (D), Rachel Mata ${ }^{2}$ and Adolfo Andrade-Cetto ${ }^{1, *(D)}$ \\ 1 Laboratory of Etnofarmacology, Faculty of Sciences, National Autonomus University of Mexico, \\ Mexico City 4510, Mexico; soniaer@ciencias.unam.mx \\ 2 Faculty of Chemistry, National Autonomus University of Mexico, Mexico City 4510, Mexico; \\ rachel@unam.mx \\ * Correspondence: aac@ciencias.unam.mx; Tel.: +52-55-622-4834
}

Academic Editor: Luigi Milella

Received: 15 July 2020; Accepted: 3 September 2020; Published: 10 September 2020

\begin{abstract}
Like in many developing countries, in Mexico, the use of medicinal plants is a common practice. Based on our own field experience, there are at least 800 plants used for treating diabetes nowadays. Thus, their investigation is essential. In this context, this work aims to provide a comprehensive and critical review of the molecules isolated from Mexican hypoglycemic plants, including their source and target tested. In the last few years, some researchers have focused on the study of Mexican hypoglycemic plants. Most works describe the hypoglycemic effect or the mechanism of action of the whole extract, as well as the phytochemical profile of the tested extract. Herein, we analyzed 85 studies encompassing 40 hypoglycemic plants and 86 active compounds belonging to different classes of natural products: 28 flavonoids, 25 aromatic compounds, other than flavonoids, four steroids, 23 terpenoids, 4 oligosaccharides, and 1 polyalcohol. These compounds have shown to inhibit $\alpha$-glucosidases, increase insulin secretion levels, increase insulin sensitivity, and block hepatic glucose output. Almost half of these molecules are not common metabolites, with a narrow taxonomic distribution, which makes them more interesting as lead molecules. Altogether, this analysis provides a necessary inventory useful for future testing of these active molecules against different hypoglycemic targets, to get a better insight into the already described mechanisms, and overall, to contribute to the knowledge of Mexican medicinal plants.
\end{abstract}

Keywords: Mexican medicinal plants; hypoglycemic; $\alpha$-glucosidase inhibitor; insulin sensitizer; insulin secretion

\section{Introduction}

Diabetes mellitus is a long-term condition that occurs when there are high glucose levels in a person's blood because their body cannot produce any or enough insulin or cannot effectively use the insulin it produces. Type 2 diabetes (T2D), due to a progressive loss of adequate $\beta$-cell insulin secretion frequently on the background of insulin resistance [1], accounts for nearly $90 \%$ of cases. The International Diabetes Federation estimated 463.0 million people living with T2D worldwide, Mexico ranks in sixth place, with 12.8 million diabetics [2]. Due to the idiosyncrasy of the Mexican population, normally, type 2 diabetic patients mainly in the rural areas of the country use a combination of medicinal plants and prescribed medicines [3]. In Mexico, at least 300 plants have been reported as hypoglycemics [4] but based on our own field experience [5,6], we estimate that at least 800 plants are used nowadays for treating diabetes.

Medicinal plants have been a resource for healing in local communities around the world. Still, $85 \%$ of the world's population depends on plants for primary healthcare [7]. In addition, they are an important resource for drug discovery, with $80 \%$ of all synthetic drugs deriving from them [8]. It is 
important to remark that medicinal plants can lead us to the discovery of new molecules useful for the development of new drugs for treating T2D and its complications.

Diverse strategies are utilized for control T2D; first, a combination of diet and exercise is in order; then, patients are prescribed oral hypoglycemic agents, initially a single drug, and later, a combination of two or more drugs. Patients can remain with exercise, diet, and oral hypoglycemic agents for a long time, providing they follow a healthy lifestyle. When this does not happen, they receive an oral hypoglycemic, first as monotherapy and then as a combination; if this does not control the blood glucose levels then external insulin is prescribed. The starting point for living well with diabetes is an early diagnosis, the longer a person lives with undiagnosed and untreated diabetes, the worse their health outcomes are likely to be. The World Health Organization (WHO) recommends a series of cost-effective interventions to improve patient outcomes. These interventions include blood glucose control through diet, physical activity, and, if necessary, medication [9]. While the American Diabetes Association (ADA) remarks that lifestyle changes such as dietary modification and increased physical activity can be very effective in improving glycemic control, over the long-term, most individuals with T2D will require medications to achieve glycemic control [10].

Until the beginning of the 1990s, sulfonylureas and metformin were the essential oral hypoglycemic agents available. Since then, new therapeutic agents have appeared in the pharmaceutical market. For example, acarbose, an alfa glucosidase inhibitor (AGI), was launched in Germany in 1990; the thiazolidinediones (TZD) insulin sensitizers, in 1996; exenatide, a glucagon-like peptide 1 (GLP1) receptor agonist, in 2005; sitagliptin, a dipeptidyl peptidase 4 (DPP-4) inhibitor, in 2006; and canagliflozin, a sodium-glucose cotransporter 2 (SGLT-2) inhibitor, in 2013 [11]. All these compounds have targets never described before. Acarbose and exenatide are natural products; other AGIs derive from natural products while metformin and canagliflozin are inspired by natural products. New targets to control hyperglycemia continuously appear, as we understand better the pathophysiology of T2D.

The research of traditional medicine can lead us to the discovery of new hypoglycemic compounds, associated with the traditional use of the plant. From an ethnopharmacological perspective, it is a start line to prove molecules isolated from plants traditionally used to treat T2D, although it is an intrinsically complex task demanding a highly sophisticated multidisciplinary approach.

In the last few years, some researchers have focused on the study of Mexican hypoglycemic plants. Most works describe the hypoglycemic effect or the mechanism of action of the whole extract, as well as the phytochemical profile of the tested extract. In the best of the cases, molecules are isolated from organic extracts but not tested against specific targets.

This work aims to provide a comprehensive and critical review of the molecules isolated from Mexican hypoglycemic plants. The studies analyzed included those reporting the hypoglycemic effect (i.e., any effect useful for potentially treating diabetes, in vivo or in vitro) of Mexican medicinal plants, and which possess at least one compound related to this activity. This review will be useful to construct a database useful for future testing of these molecules against different hypoglycemic targets.

\section{Results}

For this review, we selected and analyzed eighty-five works encompassing 40 hypoglycemic plants. Altogether, eighty-six active compounds were found, including 28 flavonoids, 25 aromatic compounds, other than flavonoids, 4 steroids, 23 terpenoids, 4 oligosaccharides, and 1 polyalcohol. Table 1 summarizes their natural sources, and Figures 1-4 their corresponding structures. These compounds are representative of the major class metabolites of secondary metabolites from plants. 
Table 1. Isolated Compounds from Hypoglycemic Mexican plants.

\begin{tabular}{|c|c|c|}
\hline Plant/Family/Part & Isolated Compounds & Ref. \\
\hline Acacia angustissima (Mill.) Kuntze (Fabaceae)/Pods. & Protocatechuic acid (1); catechin (2); $\rho$-coumaric acid (3). & [12] \\
\hline $\begin{array}{c}\text { Acourtia thurberi (A.Gray) Reveal \& R.M.King } \\
\text { (Asteraceae)/Roots. }\end{array}$ & $\begin{array}{l}\text { Perezone (4); } \alpha \text {-pipitzol (5); } \beta \text {-pipitzol (6); } \\
\text { 8- } \beta \text {-D-glucopyranosyloxy-4-methoxy-5-methyl-coumarin (7). }\end{array}$ & [13] \\
\hline Acosmium panamense (Benth.) Yacolev (Fabaceae)/Roots. & $\begin{array}{l}\text { Desmethylyangonine (8); desmethylangonine-O- } \beta \text {-D-glucopyranoside }(\mathbf{9}) ; \\
\text { desmethylangonine- } O-\beta \text {-D-glucopyranosyl- }(1 \rightarrow 6)-O-\beta \text {-D-glucopyranoside }(\mathbf{1 0}) \text {. }\end{array}$ & {$[14,15]$} \\
\hline Agarista mexicana (Hemsl.) Judd. (Ericaceae)/Bark. & 12-Ursene (11); 23,24-dimethyl-24-ethyl-stigmast-25-ene (12). & {$[16,17]$} \\
\hline $\begin{array}{c}\text { Ageratina petiolaris (Moc. \& Sessé ex DC.) R. M. King \& } \\
\text { H. Rob (Asteraceae)/Aerial parts. }\end{array}$ & $\begin{array}{l}\text { Chlorogenic acid (13); L-chiro-inositol (14); } 2 \alpha \text {-iso-valeroyloxyeperuic acid (15); } \\
\text { benzyl-2-hydroxy-6-methoxybenzoate (16); benzyl-2,6-dimethoxybenzoate (17); } \\
\text { 3-methoxybenzyl 2,6-dimethoxybenzoate (18); benzyl-2-hydroxy-3,6-dimethoxybenzoate (19). }\end{array}$ & {$[18,19]$} \\
\hline Annona cherimola Mill (Annonaceae)/Leaves. & Rutin $(20)$ & [20] \\
\hline Anoda cristata (L.) Schltdl. (Malvaceae)/Aerial. & Acacetin (21); diosmetin (22). & [21] \\
\hline Artemisia ludoviciana Nutt (Asteraceae)/Aerial. & $\begin{array}{l}\text { Eupatilin (23); jaceosidin (24); arglanin (25); salvinine (26); } \\
\text { 3,5-di-O-caffeoylquinic acid (27). }\end{array}$ & [22] \\
\hline Arracacia tolucensis (Kunth) Hemsl. (Apiaceae)/Aerial. & $(S)-(+)-4^{\prime}-O$-angeloylvisamminol (28); praeruptorin A (29). & [23] \\
\hline Brickellia veronicaefolia (Khunt) Gray (Asteraceae)/Aerial. & 5,7,3'-Trihydroxy-3,6,4'-trimethoxyflavone (30). & {$[24,25]$} \\
\hline Bromelia karatas (L) (Bromeliaceae)/Aerial. & $\begin{array}{r}\beta \text {-Sitosterol-3-O- } \beta \text {-D-glucopyranoside (31); } \rho \text {-coumaric acid (3); } \\
\text { cirsiliol-4'-O- } \beta \text {-D-glucopyranoside (32); stigmasterol (33); } \beta \text {-sitosterol (34); } \\
\text { 1-O-feruloyl-3-O- } \rho \text {-coumaroylglycerol (35); } \\
\beta \text {-D-(1-O-acetyl-3,6-O-trans-diferuloyl)-fructofuranosyl- } \alpha \text {-D-2' } 4^{\prime}, 6^{\prime}-O \text {-triacetyl-glucopyranoside } \\
\text { (36); } 1 \text {-O- } \rho \text {-coumaroyl-3-O-caffeoylglycerol (37); } 2 \text {-propyl- } \beta \text {-D-glucopyranoside (38). }\end{array}$ & {$[19,26,27]$} \\
\hline Calea oliveri B.L.Rob. \& Greenm (Asteraceae)/Aerial. & $\begin{array}{l}\text { 6-Acetyl-5-hydroxy-2,2-dimethyl-2H-chromene (39); } \\
\text { 6-hydroxyacetyl-5-hydroxy-2,2-dimethyl-2H-chromene (40); } \\
\text { 6-acetyl-5-hydroxy-2-methyl-2-hydroxymethyl-2H-chromene (41); caleins A (42) and C (43); } \\
\text { genkwanin (44); isorhamnetin (45); kaempferol (46); quercetin (47); herniarin (48); scoparone (49); } \\
\text { 4',7-dimethylapigenin (50); curcumene (51); spathulenol (52); caryophyllene oxide (53). acacetin } \\
\text { (21); 3,5-di-O-caffeoylquinic acid (27). }\end{array}$ & {$[28,29]$} \\
\hline Cecropia obtusifolia Bertol. (Urticaceae)/Leaves. & Chlorogenic acid (13); isoorientin (54). & [30-33] \\
\hline Cochlospermum vitifolium (Willd) (Bixaceae)/Bark. & $( \pm)$-Naringenin (55). & {$[34,35]$} \\
\hline Coriandrum sativum L. (Apiaceae)/Aerial. & Rutin (20). & [36] \\
\hline
\end{tabular}


Table 1. Cont

\begin{tabular}{|c|c|c|}
\hline Plant/Family/Part & Isolated Compounds & Ref. \\
\hline $\begin{array}{l}\text { Cucurbita ficifolia Bouché (Cucurbitaceae)/Fresh mature } \\
\text { and immature fruits. }\end{array}$ & $\begin{array}{c}\rho \text {-Coumaric acid (3); stigmast-7,22-dien-3-ol (56); salicin (57); stigmast-7-en-3-ol (58); } \\
\rho \text {-hydroxybenzoic acid (59). }\end{array}$ & {$[37-41]$} \\
\hline $\begin{array}{l}\text { Equisetum myriochaetum Schlecht. \& Cham. } \\
\text { (Equisetaceae)/Aerial. }\end{array}$ & $\begin{array}{c}\text { Kaempferol-3-O-sophoroside (60); kaempferol-3,7-di-O- } \beta \text {-D-glucopyranoside (61); } \\
\text { kaempferol-3-O-sophoroside-4'-O- } \beta \text {-D-glucopyranoside (62); } \\
\text { caffeoyl-methylate-4- } \beta \text {-D-glucopyranoside (63). }\end{array}$ & {$[19,32,42-44]$} \\
\hline $\begin{array}{l}\text { Eysenhardtia platycarpa Pennell \& Saff. } \\
\text { (Fabaceae)/Leaves, branches and bark. }\end{array}$ & 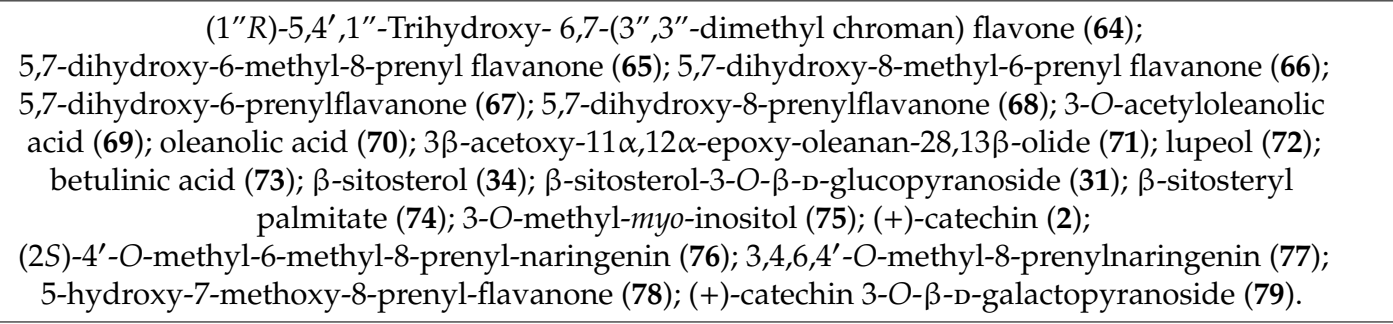 & {$[45,46]$} \\
\hline $\begin{array}{l}\text { Eysenhardtia polystachya (Ortega) Sarg. } \\
\text { (Fabaceae)/Leaves and bark. }\end{array}$ & 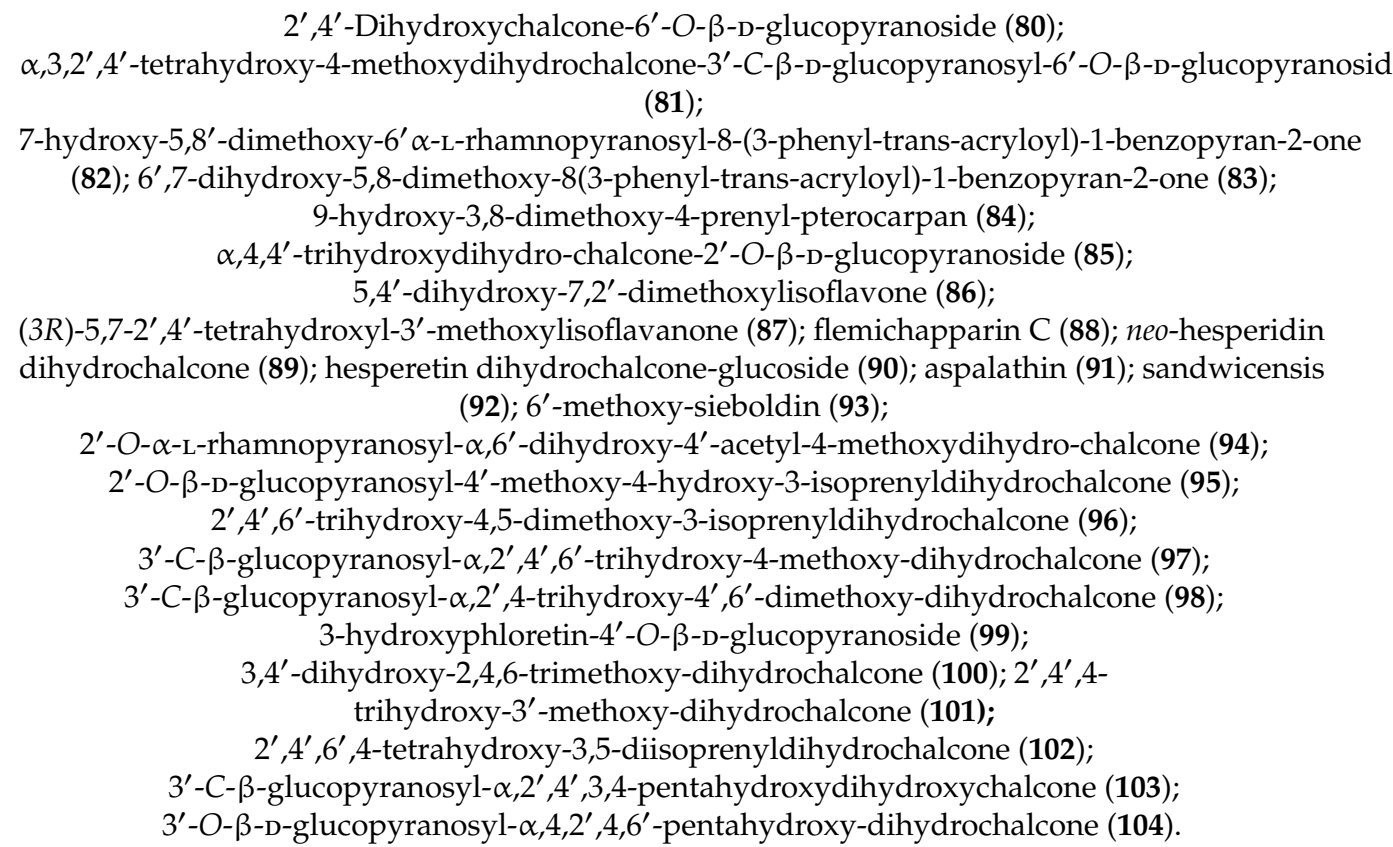 & {$[47-51]$} \\
\hline
\end{tabular}


Table 1. Cont

\begin{tabular}{|c|c|c|}
\hline Plant/Family/Part & Isolated Compounds & Ref. \\
\hline $\begin{array}{c}\text { Exostema caribaeum (Jacq.) Schult. (Rubiaceae)/Stem } \\
\text { bark. }\end{array}$ & 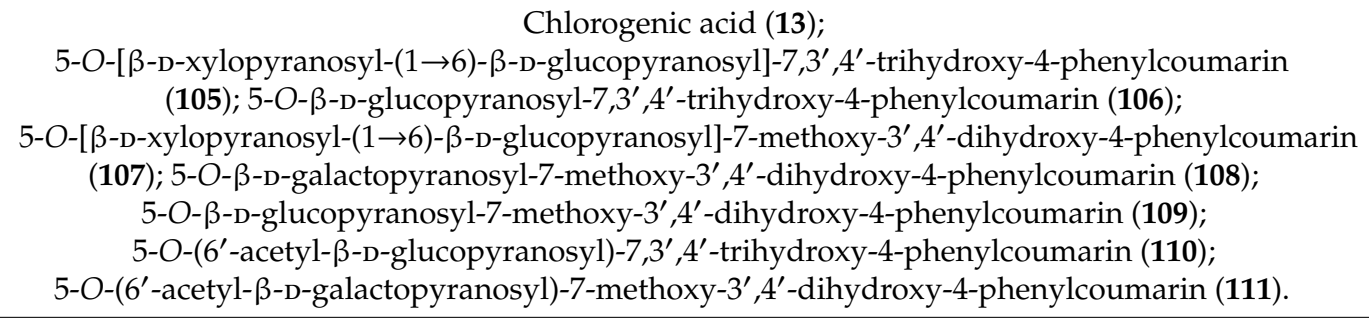 & [52] \\
\hline Hamelia patens Jacq. (Rubiaceae)/Aerial parts and leaves. & $\begin{array}{l}\text { Not isolated but identified chlorogenic acid (13); quercetin (47); caffeic acid (112); epicatechin } \\
\text { (113); catechin (2). }\end{array}$ & {$[53,54]$} \\
\hline $\begin{array}{l}\text { Hintonia latiflora (Sessé \& Moc. ex DC.) Bullock } \\
\text { (Rubiaceae)/Stem bark and leaves/endophytic fungus }\end{array}$ & 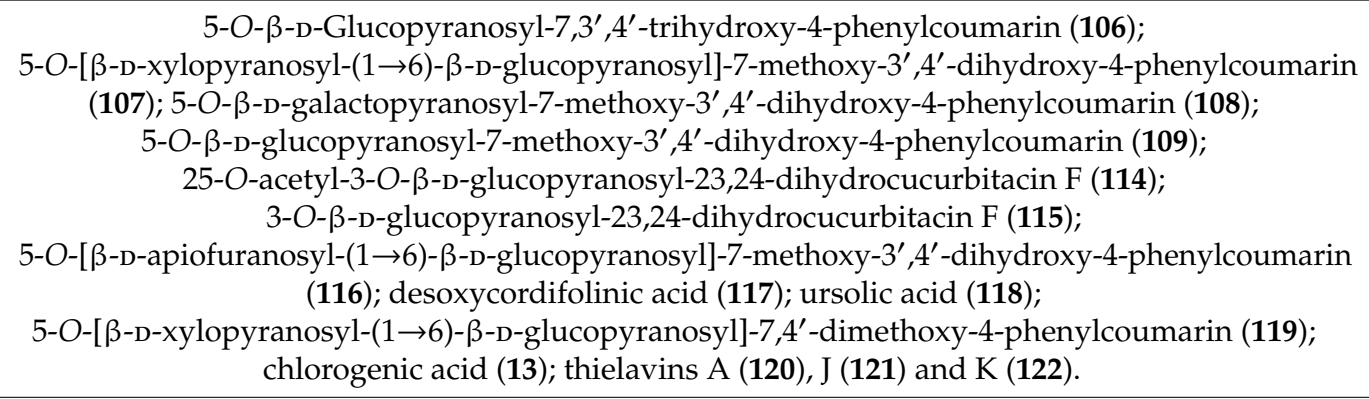 & [55-58] \\
\hline $\begin{array}{l}\text { Hintonia standleyana Bullock (Rubiaceae)/Stem bark and } \\
\text { leaves. } \\
\text { This taxon is a synonym of; Hintonia latiflora (Sessé \& } \\
\text { Moc. ex DC.) }\end{array}$ & 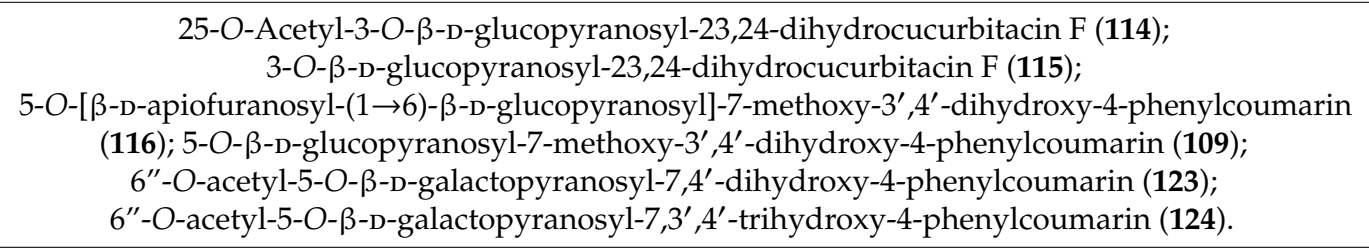 & {$[56,59]$} \\
\hline $\begin{array}{l}\text { Ibervillea sonorae (S. Watson) Greene } \\
\quad \text { (Cucurbitaceae)/Roots. }\end{array}$ & 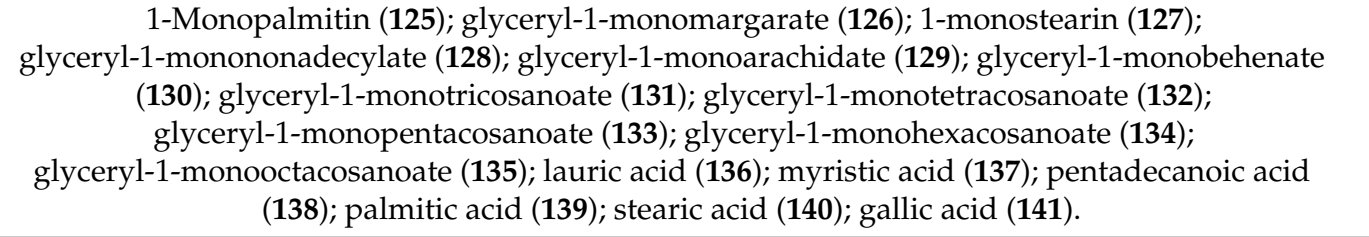 & [60-64] \\
\hline
\end{tabular}


Table 1. Cont

\begin{tabular}{|c|c|c|}
\hline Plant/Family/Part & Isolated Compounds & Ref. \\
\hline $\begin{array}{l}\text { Ipomoea pes-caprae (L.) R. Br and Ipomoea purga } \\
\text { (Wender.) Hayne (Convolvulaceae)/Roots. }\end{array}$ & $\begin{array}{l}\text { Pescapreins I (142), III (143), V (144) and IX (145); stolonoferins I (146) and III (147); murucoidins } \\
\text { IV (148), V (149), XIV (150), XVIII (151), XIX (152) and XX (153); purginosides I (154), II (155) and } \\
\text { IV (156); purgins I (157), II (158) and III (159); tricolorins A (160), E (161) and I (162); wolcottines I } \\
\text { (163), I (164), II (165), III (166) and IV (167); intrapilosin VII (168). }\end{array}$ & [65] \\
\hline Justicia spicigera Schltdl (Acanthaceae)/Leaves. & Kaempferitrin (169) & [66] \\
\hline Ligusticum porteri J.M. Coult. \& Rose (Apiaceae)/Roots. & $\begin{array}{c}\text { (Z)-6,6 }, 7,3^{\prime} \alpha \text {-Diligustilide (170); (Z)-ligustilide (171); 3-(Z)-butylidenephthalide (172); myristicin } \\
\text { (173), Ferulic acid (174). }\end{array}$ & [67] \\
\hline $\begin{array}{l}\text { Melampodium perfoliatum (Cav.) Kunth } \\
\text { (Asteraceae)/Aerial. }\end{array}$ & Perfoliatin A (175). & [68] \\
\hline $\begin{array}{l}\text { Mosannona depressa (Baill.) Chatrou } \\
\text { (Annonaceae)/Roots. }\end{array}$ & $\begin{array}{l}\text { 2-Hydroxy-3,4,5-trimethoxy-1-(2', } 4^{\prime} \text {-hydroxy-3'-dihydroxy) butylbenzene (176); } \\
\text { 2-hydroxy-3,4,5-trimethoxy-1-(2', } 3^{\prime}, 4^{\prime} \text {-hydroxy) butyl-benzene (177); } \\
\text { 3-(3-hydroxy-2,4,5-trimethoxyphenyl) propane-1,2 diol (178). }\end{array}$ & {$[32,69-71]$} \\
\hline Opuntia streptacantha Lem. (Cactaceae)/Cladodes. & 4-Hydroxyphenylacetic acid (179). & {$[72,73]$} \\
\hline $\begin{array}{l}\text { Psacalium decompositum (A.Gray) H.Rob. \& Brettell } \\
\text { (Asteraceae)/Roots. }\end{array}$ & Cacalol (180); cacalol acetate (181); cacalone (182); maturin (183); maturinone (184). & [74-77] \\
\hline $\begin{array}{l}\text { Psacalium paucicapitatum (B.L.Rob. \& Greenm.) H.Rob. } \\
\text { \& Brettell (Asteraceae)/Corms. }\end{array}$ & Kestose (185); nystose (186); fructofuranosyl-nystose (187). & [78] \\
\hline $\begin{array}{l}\text { Phoradendron reichenbachianum (Seem.) Oliv. } \\
\quad \text { (Santalaceae)/Leaves and stems. }\end{array}$ & $\begin{array}{c}\text { Moronic acid (188); morolic acid (189); oleanolic acid (70); ursolic acid (118); } \\
\text { 3,4-seco-olean-18-ene-3,28-dioic acid (190); } \alpha \text {-amyrin (191); } \beta \text {-amyrin (192); oleanolic aldehyde } \\
\text { (193); lupeol (72); lupenone (194); betulin aldehyde (195); betulon aldehyde (196); betulinic acid } \\
\text { (73); acacetin (21); betulonic acid (197); squalene (198); triacontanol (199); } \beta \text {-sitosteryl linoleate } \\
\text { (200); stigmasteryl linoleate (201); } \beta \text {-sitosterol (34); stigmasterol (33); acacetin 7-methyl ether } \\
\text { (202). }\end{array}$ & [79-81] \\
\hline Rhizophora mangle L. (Rizophoraceae)/Cortex. & $\begin{array}{c}\text { Cinchonains Ia (203) and Ib (204); epicatechin (113); catechin-3-O-rhamnopyranoside (205); } \\
\text { lyoniside (206); nudiposide (207). }\end{array}$ & {$[19,82-84]$} \\
\hline Salvia circinnata Cav. (Lamiaceae)/Aerial. & $\begin{array}{l}\text { 6,6", } 3^{\prime \prime} \text {-Trihydroxy-7, } 3^{\prime}, 7^{\prime} \text {-O-trimethyl-loniflavon (208); amarisolides B (209), C (210), D (211) } \\
\text { and E (212); amarisolide (213); pedalitin (214); apigenin-7-O- } \beta \text {-D-glucopyranoside (215); } \\
\text { 2-(3,4-dimethoxy-phenyl)-5,6-dihydroxy-7-methoxy- } 4 H \text {-chromen-4-one (216). }\end{array}$ & [85] \\
\hline Smilax aristolochiifolia Mill. (Smilaceae)/Roots. & N-trans-Feruloyltyramine (217); astilbin (218); chlorogenic acid (13). & {$[86,87]$} \\
\hline
\end{tabular}


Table 1. Cont.

\begin{tabular}{|c|c|c|}
\hline Plant/Family/Part & Isolated Compounds & Ref. \\
\hline $\begin{array}{l}\text { Smilax moranensis M. Martens \& Galeotti } \\
\text { (Smilaceae)/Roots. }\end{array}$ & trans-Resveratrol (219); 5-O-caffeoylquinic acid (220); chlorogenic acid (13). & {$[19,84,88,89]$} \\
\hline Swietenia humilis Zucc (Melaiceae)/Seeds. & $\begin{array}{c}\text { 2-Hydroxy-destigloyl-6-deoxyswietenine acetate (221); humulin B (222); } \\
\text { methyl-2-hydroxy-3- } \beta \text {-isobutyroxy-1-oxomeliac-8(30)-enate (223); } \\
\text { methyl-2-hydroxy-3- } \beta \text {-tigloyloxy-1-oxomeliac-8(30)-enate (224); humilinolide G (225); } \\
\text { humilinolide C (226); methyl-2-hydroxy-3- } \beta \text {-isobutyloyl-8 } \alpha, 30 \alpha \text {-epoxy-1-oxo-meliacate (227); } \\
\text { humilinolide H (228). }\end{array}$ & [90-92] \\
\hline Tecoma stans (L.) Juss. ex Kunth (Bignoniaceae)/Leaves. & $\begin{array}{l}\text { Chrysoeriol (229); apigenin (230); luteolin (231); verbascoside (232); } \\
\text { luteolin-7-O-glucopyranoside (233). }\end{array}$ & {$[93,94]$} \\
\hline Turnera diffusa Willd. ex Schult. (Passifloraceae)/Aerial. & Teuhetenone A (234). & [95] \\
\hline
\end{tabular}


<smiles>[R16]Oc1ccc(-c2oc3cc([R6])c([R4])c(O)c3c(=O)c2[R])cc1[R2]</smiles>

(20) $\mathrm{R}_{1}=\mathrm{O}$-[a-L-rhamnopyranosyl-(1-6)- $\beta$-D-glucopyranosyl], $\mathrm{R}_{2}=\mathrm{OH}, \mathrm{R}_{3}=\mathrm{H}, \mathrm{R}_{4}=\mathrm{H}, \mathrm{R}_{5}=\mathrm{H}$

(21) $\mathrm{R}_{1}=\mathrm{H}, \mathrm{R}_{2}=\mathrm{H}, \mathrm{R}_{3}=\mathrm{Me}, \mathrm{R}_{4}=\mathrm{H}, \mathrm{R}_{5}=\mathrm{H}$

(22) $\mathrm{R}_{1}=\mathrm{H}, \mathrm{R}_{2}=\mathrm{OH}, \mathrm{R}_{3}=\mathrm{Me}, \mathrm{R}_{4}=\mathrm{H}, \mathrm{R}_{5}=\mathrm{H}$

(23) $\mathrm{R}_{1}=\mathrm{H}, \mathrm{R}_{2}=\mathrm{OMe}, \mathrm{R}_{3}=\mathrm{Me}, \mathrm{R}_{4}=\mathrm{OMe}, \mathrm{R}_{5}=\mathrm{H}$

(24) $\mathrm{R}_{1}=\mathrm{H}, \mathrm{R}_{2}=\mathrm{OMe}, \mathrm{R}_{3}=\mathrm{H}, \mathrm{R}_{4}=\mathrm{OMe}, \mathrm{R}_{5}=\mathrm{H}$

(30) $\mathrm{R}_{1}=\mathrm{OMe}, \mathrm{R}_{2}=\mathrm{OH}, \mathrm{R}_{3}=\mathrm{Me}, \mathrm{R}_{4}=\mathrm{OMe}, \mathrm{R}_{5}=\mathrm{H}$

(32) $\mathrm{R}_{1}=\mathrm{H}, \mathrm{R}_{2}=\mathrm{OH}, \mathrm{R}_{3}=$ - D-glucopyranosyl, $\mathrm{R}_{4}=\mathrm{OMe}, \mathrm{R}_{5}=\mathrm{Me}$

(45) $\mathrm{R}_{1}=\mathrm{OH}, \mathrm{R}_{2}=\mathrm{OMe}, \mathrm{R}_{3}=\mathrm{H}, \mathrm{R}_{4}=\mathrm{H}, \mathrm{R}_{5}=\mathrm{H}$

(46) $\mathrm{R}_{1}=\mathrm{OH}, \mathrm{R}_{2}=\mathrm{H}, \mathrm{R}_{3}=\mathrm{H}, \mathrm{R}_{4} \mathrm{H}, \mathrm{R}_{5}=\mathrm{H}$

(47) $\mathrm{R}_{1}=\mathrm{OH}, \mathrm{R}_{2}=\mathrm{OH}, \mathrm{R}_{3}=\mathrm{H}, \mathrm{R}_{4}=\mathrm{H}, \mathrm{R}_{5}=\mathrm{H}$

(54) $\mathrm{R}_{1}=\mathrm{H}, \mathrm{R}_{2}=\mathrm{OH}, \mathrm{R}_{3}=\mathrm{H}, \mathrm{R}_{4}=\beta$-D-glucopyranosyl, $\mathrm{R}_{5}=\mathrm{H}$

(62) $R_{1}=O-\left[\beta\right.$-D-glucopyranosyl-(1-2)- $\beta$-D-glucopyranosyl], $\mathrm{R}_{2}=\mathrm{H}, \mathrm{R}_{3}=\beta$-D-glucopyranosyl, $\mathrm{R}_{4}=\mathrm{H}, \mathrm{R}_{5}=\mathrm{H}$

(169) $\mathrm{R}_{1}=\mathrm{O}$-a-L-rhamnopyranosyl, $\mathrm{R}_{2}=\mathrm{H}, \mathrm{R}_{3}=\mathrm{H}, \mathrm{R}_{4}=\mathrm{H}, \mathrm{R}_{5}=a$-L-rhamnopiranosyl

(214) $\mathrm{R}_{1}=\mathrm{H}, \mathrm{R}_{2}=\mathrm{OH}, \mathrm{R}_{3}=\mathrm{H}, \mathrm{R}_{4}=\mathrm{OH}, \mathrm{R}_{5}=\mathrm{Me}$

(215) $\mathrm{R}_{1}=\mathrm{H}, \mathrm{R}_{2}=\mathrm{H}, \mathrm{R}_{3}=\mathrm{H}, \mathrm{R}_{4}=\mathrm{H}, \mathrm{R}_{5}=\mathrm{O}-\mathrm{B}$-D-glucopyranosyl

(216) $\mathrm{R}_{1}=\mathrm{H}, \mathrm{R}_{2}=\mathrm{OMe}, \mathrm{R}_{3}=\mathrm{Me}, \mathrm{R}_{4}=\mathrm{OH}, \mathrm{R}_{5}=\mathrm{Me}$

(229) $\mathrm{R}_{1}=\mathrm{H}, \mathrm{R}_{2}=\mathrm{OMe}, \mathrm{R}_{3}=\mathrm{H}, \mathrm{R}_{4}=\mathrm{H}, \mathrm{R}_{5}=\mathrm{H}$

(231) $\mathrm{R}_{1}=\mathrm{H}, \mathrm{R}_{2}=\mathrm{OH}, \mathrm{R}_{3}=\mathrm{H}, \mathrm{R}_{4}=\mathrm{H}, \mathrm{R}_{5}=\mathrm{H}$<smiles>[R]C1Cc2c(O)cc(O)cc2O[C@H]1c1ccc(O)c(O)c1</smiles><smiles>[R20]Oc1cc([R])c(C(=O)C([R])Cc2cc([R7])c(O)c([R9])c2)c([R])c1[R]</smiles><smiles>O=C1C[C@H](c2ccc(O)cc2)Oc2cc(O)cc(O)c21</smiles>

(93) $\mathrm{R}_{1}=\mathrm{Me}, \mathrm{R}_{2}=$ - -D-glucopyranosyl, $\mathrm{R}_{3}=\mathrm{H}, \mathrm{R}_{4}=\mathrm{H}, \mathrm{R}_{5}=\mathrm{OH}, \mathrm{R}_{6}=\mathrm{H}, \mathrm{R}_{7}=\mathrm{H}$

(96) $\mathrm{R}_{1}=\mathrm{H}, \mathrm{R}_{2}=\mathrm{H}, \mathrm{R}_{3}=\mathrm{H}, \mathrm{R}_{4}=\mathrm{H}, \mathrm{R}_{5}=$ prenyl, $\mathrm{R}_{6}=\mathrm{Me}, \mathrm{R}_{7}=\mathrm{Me}$

(99) $\mathrm{R}_{1}=\mathrm{H} \mathrm{R} \mathrm{R}_{2}=$ B-D-glucopyranosyl, $\mathrm{R}_{3}=\mathrm{H}, \mathrm{R}_{4}=\mathrm{H}, \mathrm{R}_{5}=\mathrm{OH}, \mathrm{R}_{6}=\mathrm{H}, \mathrm{R}_{7}=\mathrm{H}$

(102) $\mathrm{R}_{1}=\mathrm{H} \mathrm{R} \mathrm{R}_{2}=\mathrm{H}, \mathrm{R}_{3}=\mathrm{H}, \mathrm{R}_{4}=\mathrm{H}, \mathrm{R}_{5}=$ prenyl, $\mathrm{R}_{6}=\mathrm{H}, \mathrm{R}_{7}=$ prenyl

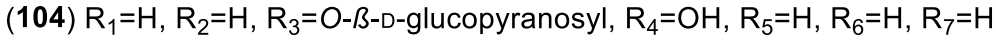<smiles>CC(=O)O[C@H]1Cc2c(O)cc3c(c2O[C@H]1c1ccc(O)c(O)c1)[C@@H](c1ccc(O)c(O)c1)CC(=O)O3</smiles><smiles>COc1cc(-c2cc(=O)c3c(O)c(O)c(OC)cc3o2)ccc1Oc1ccc(-c2cc(=O)c3c(O)c(O)c(O)c(O)c3o2)cc1OC</smiles>

Figure 1. Flavonoids from Mexican plants with hypoglycemic activity. 
<smiles>O=C(O)/C=C/c1ccc(O)cc1</smiles><smiles>COc1cc(=O)oc2c(O[C@@H]3O[C@H](CO)[C@@H](O)[C@H](O)[C@H]3O)ccc(C)c12</smiles><smiles>O=C(/C=C/c1ccc(O)c(O)c1)O[C@H]1C[C@@](O)(C(=O)O)C[C@H](O)[C@H]1O</smiles><smiles>[R]c1ccc(/C=C/c2cc(OC)cc(=O)o2)cc1</smiles><smiles>O=C(/C=C/c1ccc(O)c(O)c1)O[C@H]1C[C@](O)(C(=O)O)C[C@@H](OC(=O)/C=C/c2ccc(O)c(O)c2)[C@@H]1O</smiles>

(9) $R=O-\beta$-D-glucopyranosyl

(10) $R=O-[\beta$-D-glucopyranosyl-(1-6)- $\beta$-D-glucopyranosyl]<smiles>[R]c1cc([R])c2c(-c3ccc([R4])c([R3])c3)cc(=O)oc2c1</smiles><smiles>[R]CC(=O)c1ccc2c(c1O)C=CC(C)(C)O2</smiles>

(39) $\mathrm{R}=\mathrm{H}$

(40) $\mathrm{R}=\mathrm{OH}$

(41) $\mathrm{R}=\mathrm{OAC}$

(106) $\mathrm{R}_{1}=\mathrm{OH}, \mathrm{R}_{2}=\mathrm{O}-\beta$-D-glucopyranosyl, $\mathrm{R}_{3}=\mathrm{OH}, \mathrm{R}_{4}=\mathrm{OH}$

(107) $\mathrm{R}_{1}=\mathrm{OMe}, \mathrm{R}_{2}=\mathrm{O}$-[ $\beta$-D-xylopyranosyl-(1-6)- $\beta$-D-glucopyranosyl], $\mathrm{R}_{3}=\mathrm{OH}, \mathrm{R}_{4}=\mathrm{OH}$

(108) $\mathrm{R}_{1}=\mathrm{OMe}, \mathrm{R}_{2}=\mathrm{O}-\beta$-D-galactopyranosyl, $\mathrm{R}_{3}=\mathrm{OH}, \mathrm{R}_{4}=\mathrm{OH}$

(109) $\mathrm{R}_{1}=\mathrm{OMe}, \mathrm{R}_{2}=\mathrm{O}$ - $\beta$-D-glucopyranosyl, $\mathrm{R}_{3}=\mathrm{OH}, \mathrm{R}_{4}=\mathrm{OH}$

(116) $R_{1}=\mathrm{OMe}, \mathrm{R}_{2}=\mathrm{O}$-[ $\left[\right.$-D-apiofuranosyl-(1-6)- $\beta$-D-glucopyranosyl], $\mathrm{R}_{3}=\mathrm{OH}, \mathrm{R}_{4}=\mathrm{OH}$

(123) $\mathrm{R}_{1}=\mathrm{OH}, \mathrm{R}_{2}=6$-O-acetyl-5-O- $\beta$-D-galactopyranosyl, $\mathrm{R}_{3}=\mathrm{H}, \mathrm{R}_{4}=\mathrm{OH}$

(124) $\mathrm{R}_{1}=\mathrm{OH}, \mathrm{R}_{2}=6$-O-acetyl-5-O- $\beta$-D-galactopyranosyl, $\mathrm{R}_{3}=\mathrm{OH}, \mathrm{R}_{4}=\mathrm{OH}$<smiles>[R20]c1c(C)c(OC(=O)c2c(C)cc(O)c(C)c2O)c(C)c(C)c1C(=O)Oc1c(C)c(O)c(C(=O)O)c(C)c1O</smiles>

(120) $\mathrm{R}_{1}=\mathrm{H}, \mathrm{R}_{2}=\mathrm{Me}$

(121) $\mathrm{R}_{1}=\mathrm{Me}, \mathrm{R}_{2}=\mathrm{H}$

(122) $\mathrm{R}_{1}=\mathrm{Me}, \mathrm{R}_{2}=\mathrm{Me}$<smiles>CCC/C=C1\OC(=O)C2=C1CCC=C2</smiles><smiles>CCC/C=C1\OC(=O)c2ccccc21</smiles><smiles>O=C(O)/C=C/c1ccc(O)c(O)c1</smiles><smiles>COc1cc(/C=C/C(=O)NCCc2ccc(O)cc2)ccc1O</smiles><smiles>Oc1ccc(/C=C/c2cc(O)cc(O)c2)cc1</smiles><smiles>[R16]OC[C@H]1O[C@H](OCCc2ccc(O)c(O)c2)[C@@H](O)[C@H](O[C@@H]2O[C@H](C)[C@@H](O)[C@H](O)[C@H]2O)[C@H]1OC(=O)/C=C/c1ccc(O)c(O)c1</smiles>

Figure 2. Aromatic compounds, other than flavonoids, from Mexican plants with hypoglycemic activity. 
<smiles>CC(C)=CCC[C@H](C)C1=C(O)C(=O)C(C)=CC1=O</smiles><smiles>CC1=C(O)C(=O)[C@@]23C[C@H]1CCC2C3(C)C</smiles>

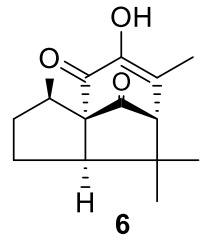<smiles>Cc1coc2c(O)c3c(c(C(C)(C)C)c12)C(C)CCC3</smiles><smiles>Cc1coc2c1[C@@](C)(O)C1=C(CCC[C@H]1C)C2=O</smiles><smiles>C=CC(C)(O)CCCC(C)C(=O)C=CC(C)(C)O</smiles><smiles>C=C1C(=O)O[C@H]2C1CC[C@]1(C)C(=O)C=CC(O)(O)C21</smiles><smiles>[R]C1[C@H](OC(C)=O)[C@@H](C)[C@@H](O)C(=O)/C=C/[C@H](C)C[C@@H]2OC(=O)C(=O)[C@H]12</smiles>

(43) $\mathrm{R}=$ Tigloyl<smiles>C=C1C(=O)OC2/C=C(\C)[C@H]3O[C@H]3/C=C(\C(=O)OC)[C@@H]1[C@@H](OC(=O)/C(C)=C\C)C2=O</smiles><smiles>C[C@]1(O)CCC[C@]2(C)CCC(=O)C=C12</smiles>

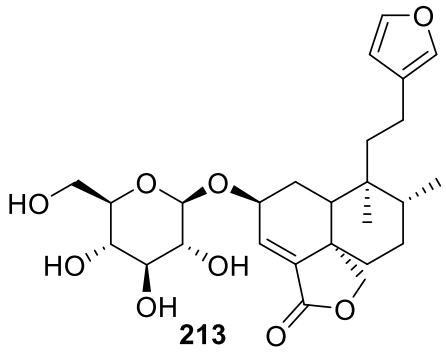

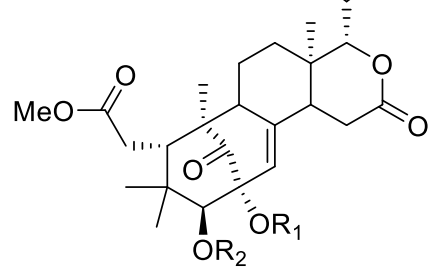

(221) $\mathrm{R}_{1}=\mathrm{H}, \mathrm{R}_{2}=$ Acetyl (224) $\mathrm{R}_{1}=\mathrm{H}, \mathrm{R}_{2}=$ Tigloyl

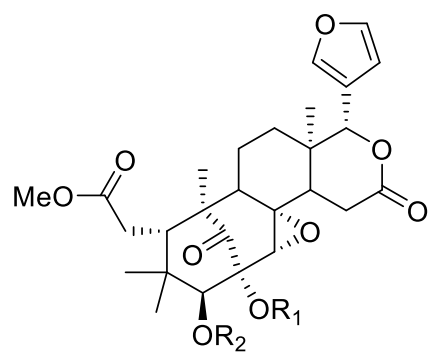

(222) $\mathrm{R}_{1}=\mathrm{H}, \mathrm{R}_{2}=$ Acetyl

(228) $R_{1}=$ Acetyl, $R_{2}=\mid$ sobutyl

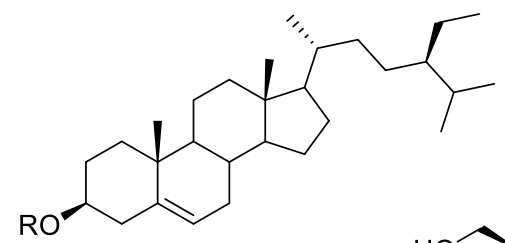

(31) $R=\beta$-D-glucopyranosyl (34) $\mathrm{R}=\mathrm{OH}$<smiles>CC1C[C@H](O)[C@H](O)[C@@H](CO)O1</smiles>

$\mathrm{HO}$

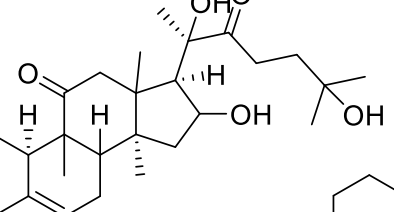<smiles>C=C(C)[C@](C)(CC)CC[C@H](C)[C@H]1CC[C@H]2[C@@H]3CC[C@H]4CCCC[C@]4(C)[C@H]3CC[C@]21C</smiles>

115

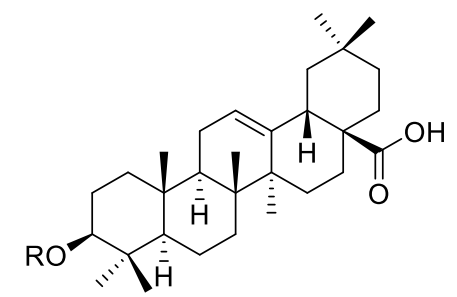

(69) $R=A c e t y$

(70) $\mathrm{R}=\mathrm{OH}$

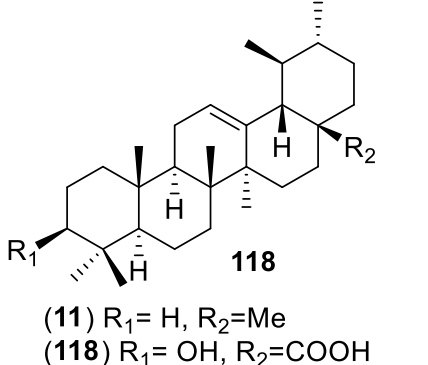

(11) $\mathrm{R}_{1}=\mathrm{H}, \mathrm{R}_{2}=\mathrm{Me}$ (118) $\mathrm{R}_{1}=\mathrm{OH}, \mathrm{R}_{2}=\mathrm{COOH}$<smiles>CC1(C)C=C2C3CCC4C5(C)CC[C@H](O)C(C)(C)C5CC[C@]4(C)[C@]3(C)CC[C@]2(C(=O)O)CC1</smiles>

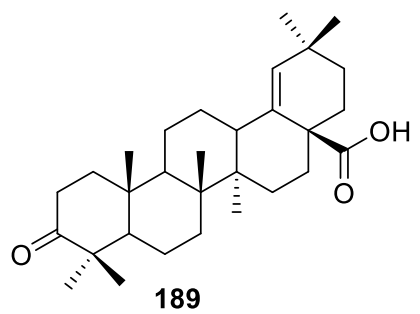

Figure 3. Terpenoids and steroids from Mexican plants with hypoglycemic activity. 
<smiles>O[C@H]1[C@H](O)[C@H](O)[C@H](O)[C@@H](O)[C@H]1O</smiles>

14

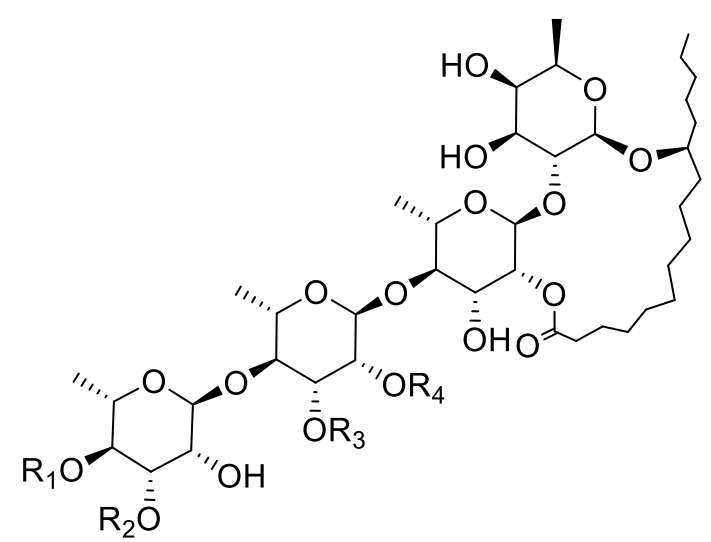

(142) $\mathrm{R}_{1}=\mathrm{H}, \mathrm{R}_{2}=\mathrm{H}, \mathrm{R}_{3}=\alpha$-L-rhamnopyranosyl, $\mathrm{R}_{4}=$ dodecanoyl (144) $\mathrm{R}_{1}=\mathrm{H}, \mathrm{R}_{2}=\mathrm{H}, \mathrm{R}_{3}=\mathrm{H}, \mathrm{R}_{4}=$ dodecanoyl

(155) $R_{1}=$ cinnamoyl, $R_{3}=ß$-D-glucopyranoyl, $R_{4}=$ decanoyl

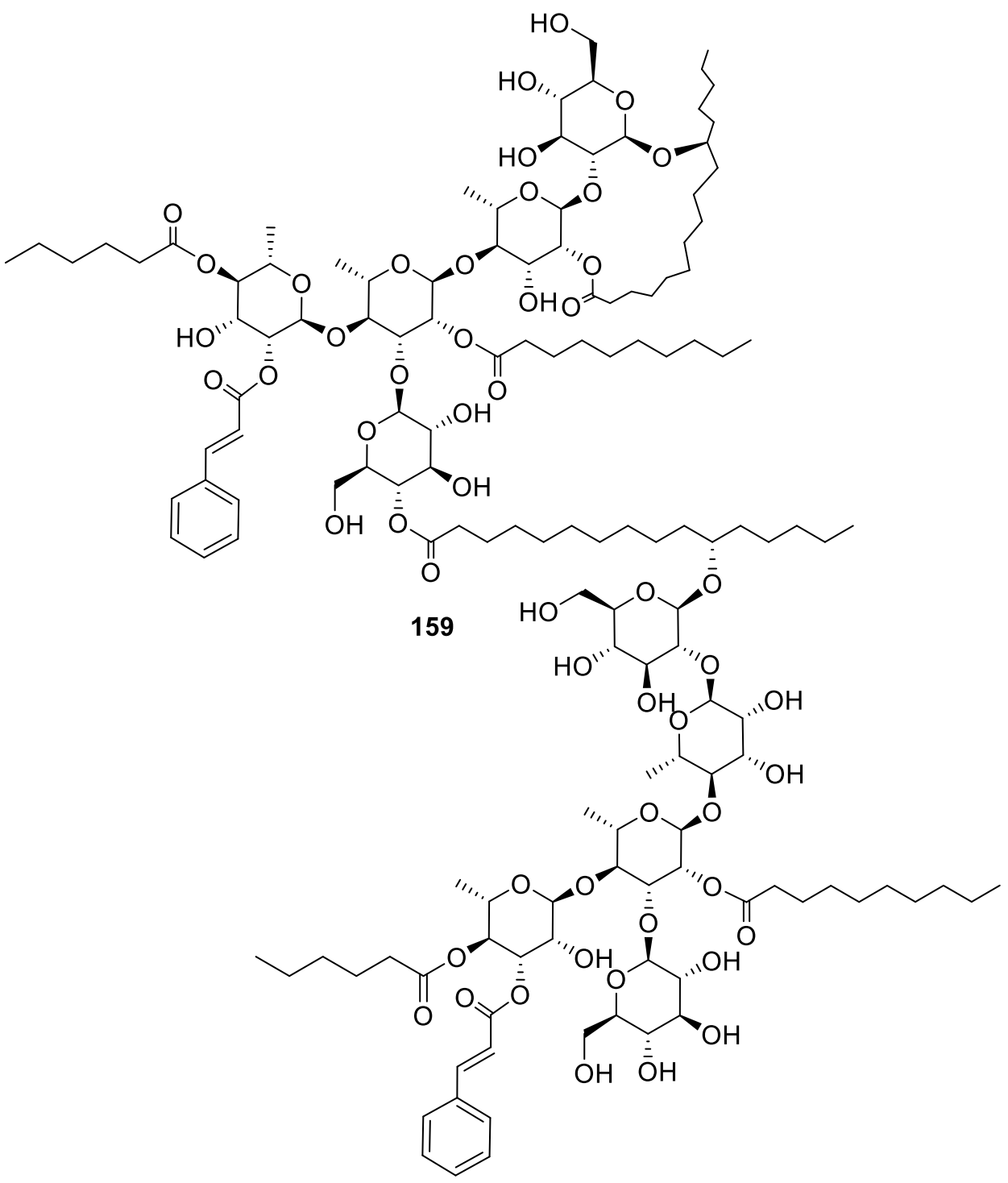

Figure 4. Carbohydrates and a cyclitol from Mexican plants with hypoglycemic activity. 
Among the flavonoids, the most abundant were flavonols (20, 30, 45-47, 62, 169), glycosides or not, and flavones (21-24, 32, 214-216, 229, 231), although a few dihydrochalcones $(\mathbf{9 6}, \mathbf{1 0 2}, \mathbf{8 0}$, 93, 99, 104), a biflavone (208), a flavanone (55), and three flavan-3-ols $(2,113,204)$ are included. The aromatic compounds comprise eight coumarins, one simple (7), and seven 4-phenylcoumarins (106-109, 116, 123 and 124); six hydroxycinnamic acids $(3,13,27,112,217,232)$; three chromenes (39-41); three depsides (120-122); two phthalides (171 and 172); two $\alpha$-pyrone glycosides (9 and 10); one stilbene (219); and one hydroxybenzoic acid (1). The terpenoids included 11 sesquiterpenes $(4-6,25,26,42,43,175,180,182,234)$, of which four were sesquiterpene lactones $(25,42,43,175)$ of the eudesmanolide, heliangolides, and melampolides types; the remaining were a nor-sesquiterpene (234); one acyclic diol (26), two eremophylanes $(\mathbf{1 8 0}, \mathbf{1 8 2})$, and one bisabolene (4) and its rearranged products $(5,6)$. Besides, one neo-clerodane diterpene (213); four limonoids $(221,222,224,228)$; one cucurbitane (115); four oleananes $(69,70,188,189)$; and two ursanes (11 and 118) completed the terpenoid family. Among the steroids, $(\mathbf{1 2}, \mathbf{3 1}, \mathbf{3 3}, \mathbf{3 4})$, compound 12 is unusual and has not been reported again from any natural source. The polyalcohol was the important cyclitol 14, and the oligosaccharides $(\mathbf{1 4 2}, \mathbf{1 4 4}$, $155,159)$ belong to the resin glycosides type (Figure 4).

The acute hypoglycemic effect was reported for 61 compounds: 19 Flavonoids $(\mathbf{2}, \mathbf{2 0}, \mathbf{2 1 - 2 4 ,} \mathbf{3 0}$, $32,45-47,54,55,62,104,113,169,204,214)$, eight coumarins $(7,106-109,116,123,124)$ two pyrones (9 and 10), one depside (122), two phthalides (171 and 172), five phenylpropanoids (3, 13, 27, 112, 219), nine sesquiterpenes $(4-6,42,43,25,180,182,234)$, two ursanes (11 and 118), three limonoids $(221,222,224)$, one cucurbitane $(115)$, four oleananes $(69,70,188,189)$ three steroids $(12,31,33)$ and one ciclytol (14). Eleven compounds displayed chronic hypoglycemic effect: Two flavonoids (2 and 20), five phenylcoumarins $(\mathbf{1 0 6}-\mathbf{1 0 9}, \mathbf{1 1 6})$, one cucurbitane (115), and three steroids $(31,33,34)$.

Forty-four compounds inhibited $\alpha$-glucosidases, in vivo and/or in vitro: 17 Flavonoids $(\mathbf{2}, \mathbf{2 0}$, 45-47, 21-23, 54, 55, 113, 208, 214-216, 229, 23), three coumarin $(7,109,116)$, three chromenes (39-41), three depsides (120-122), one phtalide (172), four phenylpropanoids $(13,27,217,232)$, eight sesquiterpenes $(4-6,26,42,43,175,234)$ including three lactones, one diterpene (213) and, four oligosaccharides $(142,144,155,159)$. Nineteen compounds increase insulin levels: Eight flavonoids $(2,20,23,24,45-47,204)$, two phenylpropanoids (3 and 112), four sesquiterpenes $(25,180,182,234)$, three limonoids (221, 224, 228), one steroid (34) and one cucurbitane (115).

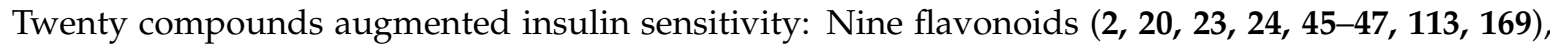
two phenylpropanoids (13 and 112), one hydroxybenzoic acid (1), seven terpenoids (70, 118, 188, 189, 221, 224, 228) and one steroid (34). Finally, nine compounds inhibit glucose 6-phosphatase activity: three flavonoids $(\mathbf{2 0}, \mathbf{2 3}, \mathbf{2 4})$, two phenylpropanoids (13 and 112), one hydroxybenzoic acid (1), and three limonoids (221, 224, 228).

Thirteen compounds of the 86-active isolated from Mexican plants have been tested elsewhere. In most cases, the studies confirm the activity found in Mexico, as in the case of $\alpha$-glucosidase inhibitors $45,47,215,229,231$, and 232.

Table 2 shows the complete list of compounds, the plant source, types of tests performed, and their mechanism of action. In addition, the activity of the compounds assessed elsewhere in the world is included. This is because, in many works, the mechanism of action of the compounds isolated from Mexican plants relies on the work performed by other authors. 
Table 2. Activity Found in the Isolated Compounds from Mexican Plants.

\begin{tabular}{|c|c|c|c|}
\hline Plant/Extract & Experiment ${ }^{1}$ & $\mathrm{AC}^{2}$ & Other Activity Found \\
\hline $\begin{array}{l}\text { Acacia } \\
\text { angustissima/Methanol } \\
\text { extract (ME). }\end{array}$ & $\begin{array}{l}\text { In vivo: ME: AHT }(25,50 \text {, and } 100 \mathrm{mg} / \mathrm{kg} \text { of bw) and OGTT } \\
(25,50, \text { and } 100 \mathrm{mg} / \mathrm{kg} \text { of bw }) \text { in healthy and STZ-treated } \\
\text { rats. BP: TC, TG, LDL and HDL [12]. } \\
\text { In vitro: Lipid peroxidation and protein content in kidney, } \\
\text { glucose incorporation assay in adipocytic cells. }\end{array}$ & $\begin{array}{l}1 \\
2 \\
3\end{array}$ & $\begin{array}{l}1 \text { Decreases blood glucose in diabetic rats; } \\
\text { insulin-sensitizing [96,97]. } 2 \text { is in vitro and in vivo } \\
\text { AG inhibitor [98], and hypoglycemic (CHT), glucose } \\
\text { oxidizing and insulin-mimetic agent [99]. } 3 \text { lowers } \\
\text { blood glucose level (CHT), glucose-6-phosphatase, } \\
\text { and fructose-1,6-bisphosphatase; increases the } \\
\text { activities of hexokinase, G6PD, and GSH by } \\
\text { increasing level of insulin; reduces the total } \\
\text { cholesterol and triglycerides in both plasma and } \\
\text { tissues i.e., liver and kidney [100]. }\end{array}$ \\
\hline $\begin{array}{l}\text { Acourtia } \\
\text { thurberi/Aque-ous } \\
\text { extract } \\
\text { (WE). }\end{array}$ & $\begin{array}{l}\text { In vivo: WE: AHT, OGTT, and OSTT in healthy and } \\
\text { STZ-treated mice using half-log interval doses }(31.6,100, \\
\text { and } 316.2 \mathrm{mg} / \mathrm{kg} \text { of bw of the extract and } 3.2,10, \text { and } 31.6 \\
\mathrm{mg} / \mathrm{kg} \text { of bw of compounds for all experiments) [13]. } \\
\text { In vitro: WE: Y-AG }\left(\mathrm{IC}_{50}=566.7 \mu \mathrm{g} / \mathrm{mL}\right)\end{array}$ & $\begin{array}{c}\mathbf{4}^{(31.6 \mathrm{mg} / \mathrm{kg})} \\
\mathbf{5}^{(3.2-31.6 \mathrm{mg} / \mathrm{kg} / 944.9 \mu \mathrm{M})} \\
\mathbf{6}^{(3.2-31.6 \mathrm{mg} / \mathrm{kg} / 944.9 \mu \mathrm{M})} \\
\mathbf{7}^{(3.2-31.6 \mathrm{mg} / \mathrm{kg} / 3.98 \mu \mathrm{M})}\end{array}$ & - \\
\hline $\begin{array}{l}\text { Acosmium } \\
\text { panamense/Aq-eous } \\
(\mathbf{W E}) \text { and butanol (BE) } \\
\text { extracts. }\end{array}$ & $\begin{array}{l}\text { In vivo: WE: AHT ( } 20 \text { and } 200 \mathrm{mg} / \mathrm{kg} \text { of bw) in STZ-treated } \\
\text { rats. BE: AHT ( } 20 \text { and } 100 \mathrm{mg} / \mathrm{kg} \text { of bw) STZ-treated rats. } \\
\text { Dose of compounds } 9 \text { and } 10 \text { for AHT: } 20 \mathrm{mg} / \mathrm{kg} \text { of bw [15]. }\end{array}$ & $\begin{array}{c}\mathbf{9}^{(20 \mathrm{mg} / \mathrm{kg})} \\
\mathbf{1 0}^{(20 \mathrm{mg} / \mathrm{kg})}\end{array}$ & - \\
\hline $\begin{array}{l}\text { Agarista } \\
\text { mexicana/Chlo-roform } \\
\text { extract }(\mathbf{C H E})\end{array}$ & $\begin{array}{l}\text { In vivo: CHE: AHT in healthy }(150 \mathrm{mg} / \mathrm{kg} \text { of bw) and } \\
\text { alloxan-treated mice }(50,100 \text { and } 150 \mathrm{mg} / \mathrm{kg} \text { of bw) and } \\
\text { OGTT in alloxan-treated rats }(150 \mathrm{mg} / \mathrm{kg} \text { of bw). Dose of } \\
\text { compounds } \mathbf{1 1} \text { and } \mathbf{1 2} \text { for AHT was } 50 \mathrm{mg} / \mathrm{kg} \text { of bw [17]. }\end{array}$ & $\begin{array}{l}\mathbf{1 1}^{(50 \mathrm{mg} / \mathrm{kg})} \\
\mathbf{1 2}^{(50 \mathrm{mg} / \mathrm{kg})}\end{array}$ & - \\
\hline $\begin{array}{l}\text { Ageratina } \\
\text { petiolaris/Aqu- } \\
\text { eous (WE) and } \\
\text { methanol (ME). }\end{array}$ & $\begin{array}{l}\text { In vivo: WE: AHT ( } 40 \mathrm{and} 160 \mathrm{mg} / \mathrm{kg} \text { of bw), OGTT ( } 160 \\
\mathrm{mg} / \mathrm{kg} \text { bw); PTT }(160 \mathrm{mg} / \mathrm{kg} \text { of bw) in STZ-NA-treated rats. } \\
\text { ME: AHT ( } 67 \text { and } 268 \mathrm{mg} / \mathrm{kg} \text { of bw) in STZ-NA-treated rats. } \\
\text { Dose of } 14 \text { for AHT was } 3.73 \mathrm{mg} / \mathrm{kg} \text { of bw [18]. } \\
\text { In vitro: WE: G6Pase Activity }\left(\mathrm{IC}_{50}=223 \mu \mathrm{g} / \mathrm{mL}\right) \text { [19]. }\end{array}$ & $\begin{array}{r}\mathbf{1 3}^{(56 \mu \mathrm{g} / \mathrm{mL})} \\
\mathbf{1 4}^{(3.73 \mathrm{mg} / \mathrm{kg})}\end{array}$ & - \\
\hline $\begin{array}{l}\text { Annona } \\
\text { cherimola/Etha-nol } \\
\text { extract (EE). }\end{array}$ & $\begin{array}{l}\text { In vivo: EE: AHT, CHT in healthy and alloxan-treated rats; } \\
\text { OGTT and OSTT in Normoglycemic rats at a dose of } 300 \\
\mathrm{mg} / \mathrm{kg} \text { of bw for the extract and } 30 \mathrm{mg} / \mathrm{kg} \text { of bw for } 20 \text { in all } \\
\text { experiments (AHT, CHT, OGTT and OSTT); } 20 \text { was active } \\
\text { in all experiments [20]. }\end{array}$ & $20^{(30 \mathrm{mg} / \mathrm{kg})}$ & - \\
\hline
\end{tabular}


Table 2. Cont

\begin{tabular}{|c|c|c|c|}
\hline Plant/Extract & Experiment ${ }^{1}$ & $\mathrm{AC}^{2}$ & Other Activity Found \\
\hline $\begin{array}{l}\text { Anoda } \\
\text { cristata/Mucil-age (M), } \\
\text { free mucilage aqueous } \\
\text { (FM-WE), aqueous } \\
\text { (WE) and organic (OE) } \\
\text { extracts. }\end{array}$ & $\begin{array}{l}\text { In vivo: WE and M tested in AHT, OGTT, and OSTT in } \\
\text { healthy and STZ-NA-treated mice (31.6, 100, and } 316 \mathrm{mg} / \mathrm{kg} \\
\text { of bw). FM-WE: AHT, OGTT, and OSTT in healthy and } \\
\text { STZ-NA-treated mice (31.6, 100, and } 316 \mathrm{mg} / \mathrm{kg} \text { of bw); } \\
\text { OGTT and CHT in metabolic syndrome induced rats (100, } \\
\text { and } 316 \mathrm{mg} / \mathrm{kg} \text { of bw). BP: cholesterol, TG, uric acid and } \\
\text { glucose. (most active). OE: OSTT in healthy and } \\
\text { STZ-NA-treated mice (31.6, 56.2, and } 100 \mathrm{mg} / \mathrm{kg} \text { of bw). } \\
\text { Doses of } 21 \text { and } 22 \text { for AHT were } 3,10 \text {, and } 31.6 \mathrm{mg} / \mathrm{kg} \text { of } \\
\text { bw [21]. }\end{array}$ & $\begin{array}{c}\mathbf{2 1}^{(3, \text { and } 31.6 \mathrm{mg} / \mathrm{kg})} \\
\mathbf{2 2}^{(3-31.6 \mathrm{mg} / \mathrm{kg})}\end{array}$ & 21 and 22 are PPAR agonists and antioxidants [101]. \\
\hline $\begin{array}{l}\text { Artemisia } \\
\text { ludoviciana/Es- } \\
\text { sential oil (EO), } \\
\text { organic (OE) and } \\
\text { aqueous (WE) } \\
\text { extracts. }\end{array}$ & $\begin{array}{l}\text { In vivo: EO, OE, and WE tested in AHT, OGTT, and OSTT } \\
\text { in healthy and STZ-treated mice ( } 31.6,100 \text {, and } 316 \mathrm{mg} / \mathrm{kg} \\
\text { of bw). Isolated compounds: Cotreatment with Ca2 }{ }^{+} \text {and } \\
\mathrm{K}^{+} \text {ion channels regulators }(17.7 \mathrm{mg} / \mathrm{kg} \text { bw); the doses of } 23 \\
\text { and } 25 \text { for AHT were } 5.6,17.7 \text {, and } 31.6 \mathrm{mg} / \mathrm{kg} \text { of bw. } \\
\text { In vitro: Y-AG for isolated compounds [22]. }\end{array}$ & 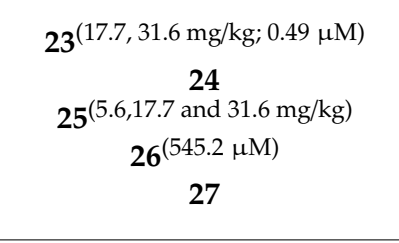 & $\begin{array}{l}23 \text { and } 24 \text { lowers blood glucose levels through the } \\
\text { up-regulation of GK activity, plasma insulin and } \\
\text { adiponectin concentration, downregulated G6Pase } \\
\text { and PEPCK activities, and sustained pancreatic } \beta \text {-cell } \\
\text { function [102,103]. 27: inhibits AG [104]. }\end{array}$ \\
\hline $\begin{array}{l}\text { Arracacia } \\
\text { tolucensis/Hex-ane } \\
\text { (HE), ethyl acetate } \\
\text { (EAE) and ethanol } \\
\text { (EE) extracts. }\end{array}$ & $\begin{array}{l}\text { In vivo: HE, EAE, EE: CHT }(250 \mathrm{mg} / \mathrm{kg} \text { of bw). Hematic } \\
\text { biometry and BP: urea, creatinine, cholesterol, TG, HDL, } \\
\text { LDL, VLDL, AST, ALT, and bilirubin; EAE was the most } \\
\text { active) [23]. }\end{array}$ & $\begin{array}{l}\text { no compounds were tested } \\
\text { in this experiment }\end{array}$ & - \\
\hline $\begin{array}{l}\text { Brickellia veronicaefolial } \\
\text { Essential oil (EO), } \\
\text { chloroform }(\text { CHE) and } \\
\text { organic }(\mathbf{O E}) \text { extracts. }\end{array}$ & $\begin{array}{l}\text { In vivo: OE and EO: AHT, OGTT in healthy and } \\
\text { STZ-NA-treated mice (OE doses: 30, 100, and } 300 \mathrm{mg} / \mathrm{kg} \text { of } \\
\text { bw; EO doses: } 10 \mathrm{mg} / \mathrm{kg} \text { of bw). CHE: isolation of } \\
\text { compounds for testing in AHT in healthy and } \\
\text { alloxan-treated mice. The doses of } 30 \text { for AHT were } 10,25 \text {, } \\
\text { and } 50 \mathrm{mg} / \mathrm{kg} \text { of bw [24]. }\end{array}$ & $3 \mathbf{0}^{(50 \mathrm{mg} / \mathrm{kg})}$ & - \\
\hline $\begin{array}{l}\text { Bromelia } \\
\text { karatas/Ethanol:water } \\
(\mathbf{E W E}) \text {, aqueous }(\mathbf{W E}) \\
\text { and organic }(\mathbf{O E}) \\
\text { extracts. }\end{array}$ & $\begin{array}{c}\text { In vivo: WE tested in AHT ( } 35 \mathrm{and} 350 \mathrm{mg} / \mathrm{kg} \text { of bw), CHT } \\
(218 \mathrm{mg} / \mathrm{kg} \text { of bw) and PTT }(218 \mathrm{mg} / \mathrm{kg}) \text { in STZ-NA rats. } \\
\text { EWE in AHT ( } 30 \text { and } 350 \mathrm{mg} / \mathrm{kg} \text { of bw) in STZ-NA rats. BP: } \\
\text { HbA1c, HDL, TG and cholesterol. The doses of } \mathbf{3 1}, \mathbf{3} \text { and } \mathbf{3 2} \\
\text { for AHT were } 72,3.63 \text {, and } 1.8 \mathrm{mg} / \mathrm{kg} \text { of bw, respectively } \\
\text { [26,27]. } \\
\text { In vitro: G6Pase Activity [19]. }\end{array}$ & $\begin{array}{l}31^{(72 \mathrm{mg} / \mathrm{kg})} \\
\mathbf{3 2}^{(1.8 \mathrm{mg} / \mathrm{kg})} \\
\mathbf{3}^{(3.63 \mathrm{mg} / \mathrm{kg})} \\
\mathbf{3 3}\end{array}$ & $\begin{array}{c}31 \text { and } 33 \text { have hypoglycemic effects in STZ-NA rats } \\
\text { treated with doses of } 0.25 \text { and } 0.50 \mathrm{mg} / \mathrm{kg} \text { for } 21 \text { days } \\
\text { to improve biochemical and hematological } \\
\text { parameters [105]. }\end{array}$ \\
\hline
\end{tabular}


Table 2. Cont.

\begin{tabular}{|c|c|c|c|}
\hline Plant/Extract & Experiment ${ }^{1}$ & $\mathrm{AC}^{2}$ & Other Activity Found \\
\hline $\begin{array}{l}\text { Calea oliveri/Aqueo-us } \\
\text { extract (WE) and } \\
\text { essential oil (EO). }\end{array}$ & $\begin{array}{c}\text { In vivo: WE tested in AHT, OGTT, and OSTT in healthy and STZ-NA } \\
\text { mice (dose of } 56,100 \text {, and } 316 \mathrm{mg} / \mathrm{kg} \text { of bw for all experiments). EO: } \\
\text { OSTT ( } 31.6,100 \text { and } 316 \mathrm{mg} / \mathrm{kg} \text { of bw). The dose of } 39 \text { for OSTT were } \\
\text { 5.6, } 10 \text {, and } 31.6 \mathrm{mg} / \mathrm{kg} \text { of bw; the dose of both } 42 \text { and } 43 \text { for OSTT } \\
\text { were } 3.16,7 \text { and } 10 \mathrm{mg} / \mathrm{kg} \text { of bw. } \\
\text { In vitro: Y-AG for WE }\left(\mathrm{IC}_{50}=0.169 \mathrm{mg} / \mathrm{mL}\right) \text { and isolated } \\
\text { compounds }[28,29] .\end{array}$ & 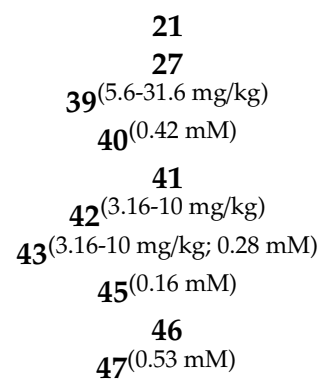 & $\begin{array}{c}46 \text { Restores PA-induced loss of } \beta \text {-cell mass and } \\
\text { function through AMPK/mTOR-mediated } \\
\text { autophagy [106]; inhibits AG [107]. } 45 \text { and } 47 \\
\text { Increase glucose uptakes in skeletal muscle by } \\
\text { activating the JAK/STAT pathway, and by } \\
\text { CaMKK } \beta / A M P K \text { and insulin signalling pathways, } \\
\text { respectively [108]. }\end{array}$ \\
\hline $\begin{array}{l}\text { Cecropia } \\
\text { obtusifolia/But-anol } \\
\text { (BE) and aqueous } \\
\text { (WE) extracts. }\end{array}$ & $\begin{array}{l}\text { In vivo: WE tested in AHT ( } 90 \text { and } 150 \mathrm{mg} / \mathrm{kg} \text { of bw) in STZ-treated } \\
\text { rats. CHT in diagnosed type } 2 \text { diabetic patients. BP: Serum glucose, } \\
\text { cholesterol, TG and insulin levels were determined every } 15 \text { days; } \\
\text { HbA1c, ALT, AST, and ALKP measured every month. BE: AHT (9 } \\
\text { and } 15 \mathrm{mg} / \mathrm{kg} \text { of bw), OMTT ( } 96 \mathrm{mg} / \mathrm{kg} \text { of bw) in STZ-NA-treated } \\
\text { rats. The dose of both } 13 \text { and } 54 \text { for AHT were } 10 \mathrm{mg} / \mathrm{kg} \text { of bw). } \\
\text { In vitro: Y-AG for BE (IC } 50=14 \mu \mathrm{g} / \mathrm{mL}) \text {; adipogenesis and } \\
\text { 2-NBDglucose uptake in 3T3-F442A murine adipocytes [30-32]. }\end{array}$ & $\begin{array}{l}\mathbf{1 3}^{(10 \mathrm{mg} / \mathrm{kg})} \\
\mathbf{5 4}^{(10 \mathrm{mg} / \mathrm{kg})}\end{array}$ & 54 Inhibits AG [109]. \\
\hline $\begin{array}{l}\text { Cochlospermum } \\
\text { vitifolium/Hex- } \\
\text { ane (HE), } \\
\text { dichlorometh-ane } \\
\text { (DE) and methanol } \\
\text { (ME) extracts. }\end{array}$ & $\begin{array}{l}\text { In vivo: HE and DE assay in AHT }(120 \mathrm{mg} / \mathrm{kg} \text { of bw) in healthy and } \\
\text { STZ-NA-treated rats. ME: in AHT }(100 \mathrm{mg} / \mathrm{kg} \text { of bw), OGTT }(100 \\
\mathrm{mg} / \mathrm{kg} \text { of bw), CHT (100 mg/kg of bw) in healthy and } \\
\text { STZ-NA-treated rats. BP: Glucose, total cholesterol, HDL and TG. } \\
\text { In vitro: Hepatoprotective activity assay and RI-AG for ME (IC } 50= \\
1.9 \mathrm{mg} / \mathrm{ML}) \text { [34,35]. }\end{array}$ & 55 & $\begin{array}{l}55 \text { Could prevent functional changes in vascular } \\
\text { reactivity in diabetic rats through nitric oxide- and } \\
\text { no prostaglandin-dependent pathways [110]. }\end{array}$ \\
\hline $\begin{array}{l}\text { Coriandrum } \\
\text { sativum/Aque-ous } \\
\text { extract (WE). }\end{array}$ & $\begin{array}{l}\text { In vivo: WE tested in OSTT }(100,300 \text {, and } 500 \mathrm{mg} / \mathrm{kg} \text { of bw) in } \\
\text { healthy rats. The dose of } 20 \text { for OSTT was } 50 \mathrm{mg} / \mathrm{kg} \text { of bw). } \\
\text { In vitro: Y-AG for WE }\left(\mathrm{IC}_{50}=1.63 \mathrm{mg} / \mathrm{mL}\right)[36] .\end{array}$ & $20^{(50 \mathrm{mg} / \mathrm{kg})}$ & - \\
\hline $\begin{array}{l}\text { Cucurbita ficifolia/Juice } \\
\text { (J) and aqueous (WE) } \\
\quad \text { extracts. }\end{array}$ & $\begin{array}{c}\text { In vivo: } \mathrm{J} \text { tested in AHT ( } 4 \mathrm{ml} / \mathrm{kg}) \text { in Type } 2 \text { diabetic patients with } \\
\text { moderate hyperglycemia; AHT }(125,250,500,594.49,750,1000, \\
\text { and } 1250 \mathrm{mg} / \mathrm{kg} \text { of bw) and CHT }(1000 \mathrm{mg} / \mathrm{kg} \text { of bw) in healthy and } \\
\text { alloxan-treated mice. EW: CHT }(200 \mathrm{mg} / \mathrm{kg} \text { of bw) in STZ-treated } \\
\text { mice }[37,39,41] \text {. } \\
\left.\text { In vitro: Effect on [Ca2 }{ }^{+}\right] \text {in } \text { RINm5F cells. Viability assays using } \\
\left.\text { DRAQ7TM probe. Participation of C. ficifolia as regulator of [Ca2 }{ }^{+}\right] \mathrm{i} \\
\text { through } \mathrm{K}^{+} \text {ATP channels [40]. }\end{array}$ & 3 & - \\
\hline
\end{tabular}


Table 2. Cont.

\begin{tabular}{|c|c|c|c|}
\hline Plant/Extract & Experiment $^{1}$ & $\mathrm{AC}^{2}$ & Other Activity Found \\
\hline $\begin{array}{l}\text { Equisetum } \\
\text { myriochaetum/Aqueous } \\
\quad(\mathbf{W E}) \text { and } \\
\text { butanol (BE) extracts. }\end{array}$ & $\begin{array}{l}\text { In vivo: WE and BE assayed in AHT (7 and 13, } 8 \text { and } 16 \\
\mathrm{mg} / \mathrm{kg} \text { of bw for WE and BE, respectively) in STZ-treated } \\
\text { rats. WE tested in AHT ( } 330 \mathrm{mg} / \mathrm{kg} \text { of bw) in type } 2 \text { diabetic } \\
\text { patients. BP: Glucose, TG, cholesterol, and glycated } \\
\text { hemoglobin. OMTT ( } 96 \mathrm{mg} / \mathrm{kg} \text { of bw) and PTT ( } 330 \mathrm{mg} / \mathrm{kg} \\
\text { of bw) in STZ-treated rats. Dose not reported for } 62 \text { in AHT. } \\
\text { In vitro: G6Pase activity and Y-AG for WE [19,32,43,44]. }\end{array}$ & 62 & - \\
\hline $\begin{array}{l}\text { Eysenhardtia } \\
\text { platycarpa/Met-hanol } \\
\text { extract (ME). }\end{array}$ & $\begin{array}{l}\text { In vivo: ME tested in AHT }(30,100, \text { and } 300 \mathrm{mg} / \mathrm{kg} \text { of bw) } \\
\text { in STZ-treated rats. The doses of } 69 \text { for AHT were 3.1, 10, } \\
\text { and } 31 \mathrm{mg} / \mathrm{kg} \text { of bw }[45,46] .\end{array}$ & $\begin{array}{c}69(31 \mathrm{mg} / \mathrm{kg}) \\
2 \\
70 \\
34\end{array}$ & $\begin{array}{l}70 \text { Acts as hypoglycemic and anti-obesity agent } \\
\text { mainly through reducing the absorption of glucose, } \\
\text { decreasing endogenous glucose production, } \\
\text { increasing insulin sensitivity, improving lipid } \\
\text { homeostasis, and weight regulation [111]. }\end{array}$ \\
\hline $\begin{array}{c}\text { Eysenhardtia } \\
\text { polystachya/A-queous } \\
\text { (WE) and } \\
\text { methanol: water } \\
\text { (MWE) extracts. }\end{array}$ & $\begin{array}{l}\text { In vivo: WE tested in AHT in alloxan-treated mice. MWE } \\
\text { in AHT }(100,200, \text { and } 400 \mathrm{mg} / \mathrm{kg} \text { of bw) in STZ-treated } \\
\text { mice; } \mathrm{CHT}(400 \mathrm{mg} / \mathrm{kg} \text { of bw) in STZ-treated mice; OGTT } \\
(400 \mathrm{mg} / \mathrm{kg} \text { of bw) in normal and STZ-treated mice. } \\
\text { Compound 104: Tested in experimental diabetic } \\
\text { nephropathy model to study pathological changes in the } \\
\text { kidney (dose: } 100 \mathrm{mg} / \mathrm{kg} \text { of bw) [47-51]. } \\
\text { In vitro: MWE tested for determining advanced glycation } \\
\text { end-product formation [50]. }\end{array}$ & $\begin{array}{c}93 \\
96 \\
99 \\
102 \\
104^{(100 \mathrm{mg} / \mathrm{kg})}\end{array}$ & - \\
\hline $\begin{array}{l}\text { Exostema } \\
\text { caribaeum/Aq-ueous } \\
\text { extract (WE). }\end{array}$ & $\begin{array}{l}\text { In vivo: WE tested in AHT and OSTT in healthy and } \\
\text { STZ-NA-treated mice. Doses of 100, 300, and } 500 \mathrm{mg} / \mathrm{kg} \text { of } \\
\text { bw for all experiments [52]. }\end{array}$ & $\begin{array}{c}13 \\
106\end{array}$ & - \\
\hline $\begin{array}{l}\text { Hamelia } \\
\text { patens/Ethanol:water } \\
(1: 1)(\text { EWE), aqueous } \\
\text { (WE) and methanol } \\
\text { (ME) extracts. }\end{array}$ & $\begin{array}{l}\text { In vivo: EWE and WE tested in AHT ( } 30 \text { and } 300 \mathrm{mg} / \mathrm{kg} \text { of } \\
\text { bw, and } 60 \text { and } 600 \mathrm{mg} / \mathrm{kg} \text { of bw for EWE and WE, } \\
\text { respectively) in STZ-NA-treated rats. ME assayed in CHT } \\
(35,75 \text { and } 150 \mathrm{mg} / \mathrm{kg} \text { of bw) in healthy and STZ-treated } \\
\text { rats }[53,54] . \\
\text { In vitro: Y-AG for ME }\left(\mathrm{IC}_{50}=78.3 \mu \mathrm{g} / \mathrm{mL}\right) .\end{array}$ & $\begin{array}{c}13 \\
47 \\
2 \\
112 \\
113\end{array}$ & $\begin{array}{l}112 \text { Exhibits significant potential as an antidiabetic } \\
\text { agent by suppressing the progression of type } 2 \\
\text { diabetic states that is suggested by attenuation of } \\
\text { hepatic glucose output and enhancement of adipocyte } \\
\text { glucose uptake, insulin secretion, and antioxidant } \\
\text { capacity [112]. } 113 \text { improves insulin sensitivity in } \\
\text { high fat diet-fed mice and inhibits AG [113,114]. }\end{array}$ \\
\hline
\end{tabular}


Table 2. Cont.

\begin{tabular}{|c|c|c|c|}
\hline Plant/Extract & Experiment ${ }^{1}$ & $\mathrm{AC}^{2}$ & Other Activity Found \\
\hline $\begin{array}{l}\text { Hintonia latiflora/Orga- } \\
\text { nic (OE) and aqueous } \\
\text { (WE) and endophytic } \\
\text { fungus extracts. }\end{array}$ & $\begin{array}{l}\text { In vivo: OE tested in AHT }(10,30,100, \text { and } 300 \mathrm{mg} / \mathrm{kg} \text { of } \\
\text { bw) in healthy and STZ-treated rats. In CHT ( } 50 \text { and } 100 \\
\mathrm{mg} / \mathrm{kg} \text { of bw) in STZ rats. The doses of compounds 106-109 } \\
\text { and 114-117 for CHT were } 15 \mathrm{and} 30 \mathrm{mg} / \mathrm{kg} \text { of bw. WE } \\
\text { tested in AHT }(100,300 \text { and } 500 \mathrm{mg} / \mathrm{kg} \text { of bw), OSTT (100, } \\
\text { 300, and } 500 \mathrm{mg} / \mathrm{kg} \text { of bw) in healthy and STZ-NA-treated } \\
\text { rats. The doses of } \mathbf{1 2 2} \text { for AHT and OSTT were } 3.1,10 \text {, } \\
\text { and } 31.6 \mathrm{mg} / \mathrm{kg} \text { of bw [55-58,115]. The doses of } \mathbf{1 1 6} \text { for } \\
\text { OSTT was } 50 \mathrm{mg} / \mathrm{kg} \text { of bw. } \\
\text { In vitro: Determination of hepatic glycogen, Y-AG for } \\
\text { compounds. }\end{array}$ & 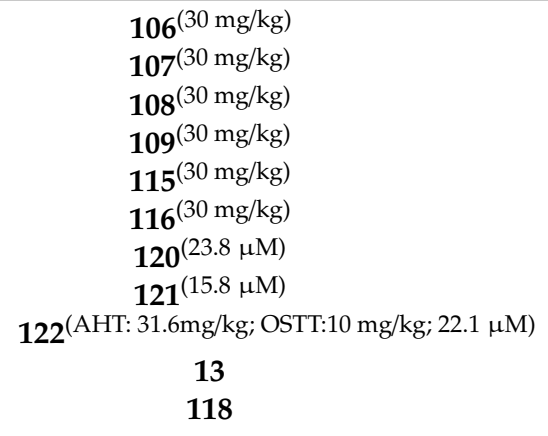 & - \\
\hline $\begin{array}{c}\text { Hintonia } \\
\text { standleyana/Or-ganic } \\
\text { extract }(\mathbf{O E}) .\end{array}$ & $\begin{array}{l}\text { In vivo: OE tested in AHT ( } 10 \text { and } 100 \mathrm{mg} / \mathrm{kg} \text { of bw) in } \\
\text { healthy and STZ-treated rats; CHT ( } 50 \text { and } 100 \mathrm{mg} / \mathrm{kg} \text { of } \\
\text { bw) in STZ rats and developing hyperglycemic situation in } \\
\text { rats. The doses of compounds 115, 116, 123, and } \mathbf{1 2 4} \text { for } \\
\text { AHT were } 10 \mathrm{mg} / \mathrm{kg} \text { of bw. The doses of both } \mathbf{1 1 5} \text { and } \mathbf{1 1 6} \\
\text { for CHT were } 15 \text { and } 30 \mathrm{mg} / \mathrm{kg} \text { of bw }[56,59] \text {. }\end{array}$ & $\begin{array}{l}\mathbf{1 1 5}^{(15 \mathrm{mg} / \mathrm{kg})} \\
\mathbf{1 1 6}^{(15 \mathrm{mg} / \mathrm{kg})} \\
\mathbf{1 2 3}^{(10 \mathrm{mg} / \mathrm{kg})} \\
\mathbf{1 2 4}^{(10 \mathrm{mg} / \mathrm{kg})} \\
\mathbf{1 0 9}\end{array}$ & - \\
\hline $\begin{array}{l}\text { Ibervillea } \\
\text { sonorae/Aque-ous } \\
\text { (WE), juice (J), } \\
\text { Dichlorometh-ane } \\
\text { (DE) and methanol } \\
\text { (ME) extracts. }\end{array}$ & $\begin{array}{l}\text { In vivo: extracts tested in AHT in healthy and } \\
\text { alloxan-treated mice (ip administration; the doses of WE } \\
\text { were } 150,300,600 \text {, and } 850 \mathrm{mg} / \mathrm{kg} \text { of bw; dose for J, DE, } \\
\text { and ME: } 300 \text { and was } 600 \mathrm{mg} / \mathrm{kg} \text { of bw). WE: Tested in a } \\
\text { murine model of obesity and hyperglycemia, induced by a } \\
\text { high-calorie diet; the relationship of these effects with } \\
\text { hepatic oxidation were observed. } \\
\text { In vitro: WE was assayed for glucose uptake in insulin- } \\
\text { sensitive, and insulin-resistant murine and human cultured } \\
\text { adipocytes; both in the absence or the presence of insulin } \\
\text { signaling pathway inhibitors, and on murine and human } \\
\text { adipogenesis [60-64]. }\end{array}$ & - & - \\
\hline $\begin{array}{c}\text { Ipomoea } \\
\text { pes-caprae/hexane (HE) } \\
\text { and chloroform (CHE) } \\
\text { extracts. }\end{array}$ & In vitro: $\mathrm{Y}-\mathrm{AG}$ of isolated compounds [65]. & $\begin{array}{l}\mathbf{1 4 2}^{(626 \mu \mathrm{M})} \\
\mathbf{1 4 4}^{(724 \mu \mathrm{M})} \\
\mathbf{1 5 5}^{(1067 \mu \mathrm{M})} \\
\mathbf{1 5 9}^{(330 \mu \mathrm{M})}\end{array}$ & - \\
\hline
\end{tabular}


Table 2. Cont.

\begin{tabular}{|c|c|c|c|}
\hline Plant/Extract & Experiment $^{1}$ & $\mathrm{AC}^{2}$ & Other Activity Found \\
\hline $\begin{array}{l}\text { Justicia spicigera/Etha- } \\
\text { nol extract (EE). }\end{array}$ & $\begin{array}{l}\text { In vivo: EE tested in OSTT ( } 100 \mathrm{mg} / \mathrm{kg} \text { of bw) in healthy } \\
\text { and STZ-NA-treated rats. Effect on the glucose uptake in } \\
\text { insulin-sensitive and insulin-resistant murine 3T3-F442A } \\
\text { and human subcutaneous adipocytes [66]. }\end{array}$ & 169 & $\begin{array}{c}169 \text { Induces hypoglycemic effect in normal and in } \\
\text { alloxan-induced diabetic rats; inhibits GLUT4 } \\
\text { mediated glucose uptake in differentiated 3T3-L1 cells } \\
\text { by interfering with the insulin signaling pathway, } \\
\text { and by directly interacting with membrane GLUT4 } \\
{[116,117] .}\end{array}$ \\
\hline $\begin{array}{l}\text { Ligusticum } \\
\text { porteri/Organic extract } \\
\text { (OE). }\end{array}$ & $\begin{array}{l}\text { In vivo: OE tested in AHT, OGTT, and OSTT in healthy and } \\
\text { STZ-NA mice; the doses were } 56.2,100 \text {, and } 316 \mathrm{mg} / \mathrm{kg} \text { of } \\
\text { bw for all experiments. The doses of } \mathbf{1 7 0}-\mathbf{1 7 1} \text { for OGTT } \\
\text { were } 10,31.2 \text { and } 56.2 \mathrm{mg} / \mathrm{kg} \text { of bw for all compounds. } \\
\text { The doses of } \mathbf{1 7 2} \text { for OSTT were } 10 \text { and } 56.2 \mathrm{mg} / \mathrm{kg} \text { of bw. } \\
\text { In vitro: Y-AG for isolated compounds [67]. }\end{array}$ & $\begin{array}{c}\mathbf{1 7 1}^{(10-56.2 \mathrm{mg} / \mathrm{kg})} \\
\mathbf{1 7 2}^{(10 \text { and } 56.2 \mathrm{mg} / \mathrm{kg} ; 2.5 \mathrm{mM})}\end{array}$ & - \\
\hline $\begin{array}{l}\text { Melampodium } \\
\text { perfoliatum/Aq-ueous } \\
\text { extract (WE). }\end{array}$ & $\begin{array}{c}\text { In vivo: OSTT in STZ-NA-treated mice for isolated } \\
\text { compound } 175 \text { (doses: } 3.16,10 \text { and } 31.6 \mathrm{mg} / \mathrm{kg} \text { of bw). } \\
\text { In vitro: RI-AG for extract ( } \mathrm{IC}_{50}=985.2 \mu \mathrm{g} / \mathrm{mL} \text { ) and } \\
\text { isolated compound [68]. }\end{array}$ & $\mathbf{1 7 5} 5^{(3.16-31.6 \mathrm{mg} / \mathrm{kg} ; 6.5 \mathrm{mM})}$ & - \\
\hline $\begin{array}{l}\text { Mosannona } \\
\text { depressa/Aqu-eous } \\
\text { (WE), butanol (BE) } \\
\text { and ethanol (EE) } \\
\text { extracts. }\end{array}$ & $\begin{array}{l}\text { In vivo: AHT in STZ-treated rats for WE ( } 40 \text { and } 80 \mathrm{mg} / \mathrm{kg} \\
\text { of bw), EE }(113 \mathrm{mg} / \mathrm{kg} \text { of } \mathrm{bw}) \text { and BE }(80 \mathrm{mg} / \mathrm{kg} \mathrm{bw}) ; \text { the } \\
\text { last one was the most active. BE tested in OMTT }(96 \mathrm{mg} / \mathrm{kg} \\
\text { of bw) and CHT ( } 50 \mathrm{mg} / \mathrm{kg} \text { of bw) in STZ-treated rats; and } \\
\text { stimulation of insulin secretion in STZ-treated rats; BP } \\
\text { measuring glucose, TG, cholesterol, and glycosylated } \\
\text { hemoglobin were measured. EE: PTT ( } 60 \text { and } 80 \mathrm{mg} / \mathrm{kg} \text { of } \\
\text { bw) in n5-STZ rats after an } 18 \text {-h fasting period. } \\
\text { In vitro: Effect on glucose-6-phosphatase activity for EE } \\
\left(\mathrm{IC}_{50}=267.62 \mu \mathrm{g} / \mathrm{mL}\right) \text { and Y-AG for BE }\left(\mathrm{IC}_{50}=267.62\right. \\
\mathrm{\mu g} / \mathrm{mL})[32,69-71] .\end{array}$ & - & - \\
\hline $\begin{array}{l}\text { Opuntia } \\
\text { streptacantha/Li-quefied } \\
\text { (LE) filtrate extract } \\
\text { (FE) and juice }(\mathbf{J}) \text {. }\end{array}$ & $\begin{array}{c}\text { In vivo: LE tested in AHT ( } 135 \mathrm{mg} / \mathrm{kg} \text { of bw) and MTT (135 } \\
\mathrm{mg} / \mathrm{kg} \text { of bw }) \text { in n5-STZ rats. FE: in AHT (12 and } 27 \mathrm{mg} / \mathrm{kg} \\
\text { of bw) and MTT (12 and } 27 \mathrm{mg} / \mathrm{kg} \text { of bw }) \text { in n5-STZ rats. J } \\
\text { in MTT ( } 4 \mathrm{~mL} / \mathrm{kg}) \text { in n5-STZ rats. } \\
\text { In vitro: RI-AG [72,73]. }\end{array}$ & - & - \\
\hline
\end{tabular}


Table 2. Cont.

\begin{tabular}{|c|c|c|c|}
\hline Plant/Extract & Experiment $^{1}$ & $\mathrm{AC}^{2}$ & Other Activity Found \\
\hline $\begin{array}{l}\text { Psacalium } \\
\text { decompositum/Aqueous } \\
(\mathbf{W E}) \text {, methanol (ME) } \\
\text { and hexane (HE) } \\
\text { extracts. }\end{array}$ & $\begin{array}{l}\text { In vivo: WE tested in AHT (50,100, 200, or } 400 \mathrm{mg} / \mathrm{kg} \text { of } \\
\text { bw) in healthy and alloxan mice; in OGTT (dose not } \\
\text { specified) in healthy rabbits; CHT (150 mg/kg of bw) in rats } \\
\text { with } 12 \text { weeks fructose feeding. ME and HE tested in AHT } \\
\text { (50,100, 200, or } 400 \mathrm{mg} / \mathrm{kg} \text { of bw for both extracts) in } \\
\text { healthy mice. The doses of } \mathbf{1 8 0 - 1 8 3} \text { for AHT were } 50 \text { and } \\
100 \mathrm{mg} / \mathrm{kg} \text { of bw [74-77]. } \\
\text { In vitro: Compounds tested in diazoxide-induced } \\
\text { relaxation of male rat aortic rings precontracted with } \\
\text { phenylephrine. }\end{array}$ & $\begin{array}{l}180 \\
182\end{array}$ & - \\
\hline $\begin{array}{c}\text { Psacalium } \\
\text { paucicapitatum } \\
\text { Aqueous extract }(\mathbf{W E}) \text {. }\end{array}$ & $\begin{array}{l}\text { In vivo: WE tested in CHT and OGTT in mice with } 12 \\
\text { weeks fructose feedings [78]. }\end{array}$ & - & - \\
\hline $\begin{array}{l}\text { Phoradendron } \\
\text { reichenbachianum/Acetone } \\
\text { extract (AE) }\end{array}$ & $\begin{array}{l}\text { In vivo: AE tested in AHT (100 mg/kg of bw) in STZ-NA } \\
\text { rats. CHT, OGTT, and OSTT for isolated compounds in } \\
\text { STZ-NA rats (the doses of all the compounds tested were } 50 \\
\mathrm{mg} / \mathrm{kg} \text { of bw) [79-81]. } \\
\text { In vitro: Inhibitory activity of compounds against protein } \\
\text { tyrosine phosphatase1B (PTP-1B). Assay for 11ß-HSD1 } \\
\text { inhibition [79]. }\end{array}$ & $\begin{array}{l}\mathbf{1 8 8}^{(50 \mathrm{mg} / \mathrm{kg})} \\
\mathbf{1 8 9}(50 \mathrm{mg} / \mathrm{kg}) \\
\mathbf{7 0}^{(50 \mathrm{mg} / \mathrm{kg})} \\
\mathbf{1 1 8}^{(50 \mathrm{mg} / \mathrm{kg})} \\
\mathbf{2 1} \\
\mathbf{3 4}\end{array}$ & $\begin{array}{l}34 \text { Attenuates insulin resistance in adipose tissue via } \\
\text { IRS-1/Akt mediated insulin signaling in high fat diet } \\
\text { and sucrose induced type-2 diabetic rats [118]. }\end{array}$ \\
\hline $\begin{array}{l}\text { Rhizophora } \\
\text { mangle/Aque-ous (WE) } \\
\text { and ethanol:water } \\
\text { (EW) extracts. }\end{array}$ & $\begin{array}{l}\text { In vivo: WE tested in AHT ( } 5.9 \text { and } 59 \mathrm{mg} / \mathrm{kg} \text { of bw), OMTT } \\
\text { ( } 56 \mathrm{mg} / \mathrm{kg} \text { of bw) in STZ-NA-treated rats. EW assayed in } \\
\text { AHT }(9 \mathrm{and} 90 \mathrm{mg} / \mathrm{kg} \text { of bw), CHT }(90 \mathrm{mg} / \mathrm{kg} \text { of bw) and } \\
\text { PTT }(90 \mathrm{mg} / \mathrm{kg}) \text { in healthy and STZ-NA rats }[19,82-84] \text {. } \\
\text { In vitro: G6Pase activity for EW }\left(\mathrm{IC}_{50}=99 \mu \mathrm{g} / \mathrm{mL}\right) \text { and } \\
\text { RI-AG [19,32]. }\end{array}$ & $\begin{array}{l}113 \\
204\end{array}$ & $\begin{array}{l}204 \text { Induces insulin secretion in vitro and in vivo } \\
\text { [119]. }\end{array}$ \\
\hline $\begin{array}{l}\text { Salvia } \\
\text { circinnata/Aqu-eous } \\
\text { extract (WE). }\end{array}$ & $\begin{array}{l}\text { In vivo: WE tested in AHT, OGTT, and OSTT in healthy } \\
\text { and STZ-NA-treated mice. Doses of 31.6, } 100 \text { and } 316 \\
\mathrm{mg} / \mathrm{kg} \text { of bw for all experiments. } \\
\text { The doses for } 213 \text { and } 214 \text { for OSTT were } 3.1,10 \text {, and } 31.6 \\
\mathrm{mg} / \mathrm{kg} \text { of bw, and 1, 3.1, and } 10 \mathrm{mg} / \mathrm{kg} \text { of bw, respectively. } \\
\text { In vitro: RI-AG [85]. }\end{array}$ & 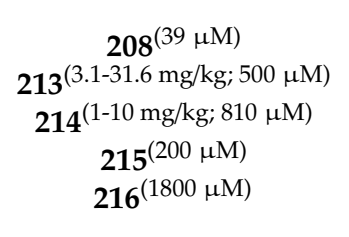 & - \\
\hline
\end{tabular}


Table 2. Cont.

\begin{tabular}{|c|c|c|c|}
\hline Plant/Extract & Experiment ${ }^{1}$ & $\mathrm{AC}^{2}$ & Other Activity Found \\
\hline $\begin{array}{l}\text { Smilax aristolochiifolia/Acetone } \\
\text { (AE), ethanol:water (EWE) and } \\
\text { aqueous (WE) extracts. }\end{array}$ & $\begin{array}{l}\text { In vivo: AE and } 2 \mathbf{1 7}(25 \mathrm{mg} / \mathrm{kg} \text { of bw) tested in the insulin } \\
\text { tolerance curve in mice with a high-caloric diet. } \\
\text { In vitro: Pancreatic } \alpha \text {-amylase and Y-AG testing for WE, EWE, } \\
\text { and compounds }[86,87] \text {. }\end{array}$ & $\begin{array}{c}217^{(25 \mathrm{mg} / \mathrm{kg})} \\
13\end{array}$ & - \\
\hline $\begin{array}{l}\text { Smilax moranensis/Aq-ueous } \\
(\mathbf{W E}) \text { and ethanol (EE) extracts. }\end{array}$ & $\begin{array}{l}\text { In vivo: WE tested in AHT ( } 20 \text { and } 200 \mathrm{mg} / \mathrm{kg} \text { of bw) in } \\
\text { n5-STZ-treated rats. EE assayed in AHT ( } 8 \text { and } 80 \mathrm{mg} / \mathrm{kg} \text { of bw), } \\
\text { CHT ( } 80 \mathrm{mg} / \mathrm{kg} \text { of bw), PTT ( } 80 \mathrm{mg} / \mathrm{kg} \text { of bw), MTT }(80 \mathrm{mg} / \mathrm{kg} \text { of } \\
\text { bw) in healthy and STZ-NA rats; and BP measuring glycated } \\
\text { hemoglobin (HbA1c) and lipid profile (HDL, TG and cholesterol). } \\
\text { In vitro: G6Pase activity for EE (IC } 50=84 \mu \mathrm{m} / \mathrm{mL}) \text { and Y-AG } \\
{[19,84,88,89] .}\end{array}$ & $\begin{array}{l}13^{(63 \mu \mathrm{g} / \mathrm{mL})} \\
219\end{array}$ & $\begin{array}{l}219 \text { Induces effects that might contribute to } \\
\text { the protection of } \beta \text { cells in diabetes; it } \\
\text { reduces insulin secretion in animals with } \\
\text { hyperinsulinemia }[120,121] .\end{array}$ \\
\hline
\end{tabular}

In vivo: WE tested in $\mathrm{AHT}(31.6,100$, and $316 \mathrm{mg} / \mathrm{kg}$ of bw)

OGTT $(31.6,100$, and $316 \mathrm{mg} / \mathrm{kg}$ of bw), OSTT $(100,177$, and 316 $\mathrm{mg} / \mathrm{kg}$ of bw) in healthy and STZ-NA-treated mice; OGTT (100 and $316 \mathrm{mg} / \mathrm{kg}$ of bw) in metabolic syndrome in Sprague Dawley rats (FF-MS) . CHT (100 and $316 \mathrm{mg} / \mathrm{kg}$ of bw) in FF-MS-induced rats; $\mathrm{BP}$ measuring glucose, TG, total cholesterol and uric acid. Swietenia humilis/Aqueo-us The doses of all 221, 222, and 224 for AHT and OGTT were 3.16 , extract (WE). 10 and $31.6 \mathrm{mg} / \mathrm{kg}$ of bw.

In vitro: Measurement of hepatic glycogen content and serum insulin levels. Studies on INSE1, H4IIE and C2C12 cells to assess

insulin secretion; glucose uptake and mitochondrial

bioenergetics, respectively; and glucose-6-phosphatase inhibition

$$
\text { [90-92]. }
$$

In vivo: WE tested in AHT (500 mg/kg of bw), CHT $(125,250$,

Tecoma stans/Aqueous (WE) and ethanol:water (EWE) extracts.

Turnera diffusa/Metha-nol extract (ME)

and $500 \mathrm{mg} / \mathrm{kg}$ of bw), OGTT ( $500 \mathrm{mg} / \mathrm{kg}$ of bw) and OSTT (125,

250 , and $500 \mathrm{mg} / \mathrm{kg}$ of bw) in healthy and STZ-treated rats.

In vitro: Pancreatic lipase inhibition for EWE (30\% inhibition) and compounds [93,94].

$229(85.03 \%)$

$231^{(32.83 \%)}$

$232^{(36.29 \%)}$

In vivo: ME assayed in AHT in normoglycemic and alloxan-treated mice. The doses of $\mathbf{2 3 4}$ for AHT were 1 and $5 \quad \mathbf{2 3 4 ^ { ( 1 - 5 m g / k g }}$

$$
\mathrm{mg} / \mathrm{kg} \text { of bw. }
$$

${ }^{1}$ AHT: Acute hypoglycemic test. OGTT: Oral glucose tolerance test. OSTT: Oral sucrose tolerance test. OMTT: Oral maltose tolerance test. CHT: Chronic hypoglycemic test. Y-AG

Yeast $\alpha$-glucosidase inhibition. RI-AG: Rat intestinal $\alpha$-glucosidase inhibition. BP: Blood Biochemical profile. PTT: Pyruvate tolerance test. ${ }^{2}$ Active compound with defined mechanism of action: $\alpha$-glucosidase; increasing plasmatic insulin levels; insulin sensitivity; other mechanisms; unknown mechanism of action, (active dose/IC 50$)$. 
It is important to mention that most compounds listed in Table 1; Table 2 were isolated from organic extracts, and in a few cases from the traditionally aqueous preparation. Only in one case, the active principle of a hypoglycemic essential oil was established [28,29].

From the nine types of pharmacological agents currently used to treat T2D (sulfonylureas, meglitinides, biguanides, thiazolidinediones, alpha glucosidase inhibitors, DPP-4 inhibitors, bile acid sequestrants, dopamine agonists, and sodium-glucose transport protein 2 inhibitors), the compounds obtained from Mexican hypoglycemic plants share one or more of their mechanisms of action. The mechanisms most frequently found were $\alpha$-glucosidase inhibition, insulin secretion or sensitization, and/or inhibition of hepatic glucose output (HGO). The $\alpha$-glucosidase inhibitory effect is clear from the assays; the hypoglycemic effect is only throughout the inhibition of the enzyme. In addition, the assays required to demonstrate the activity in vivo or in vitro are easier to perform. When the compounds increase insulin plasmatic levels, the mechanism action, however, is not straightforward because they can target the pancreatic $\beta$-cells, increase GLP1 production in the gut, inhibit DPP4, or even act through unknown mechanisms. Those behaving as insulin sensitizers might be affecting different pathways.

\subsection{Glucosidases Inhibitors}

$\alpha$-Glucosidase is the key enzyme involved in the digestion of carbohydrates; inhibitors of this enzyme can slow down the liberation of absorbable monosaccharides from dietary complex carbohydrates. The action mechanism of AGIs causes a decrease in glucose levels as well as osmotic effects. The disaccharides which are not digested will endure in the intestinal lumen and may lead to side effects such as diarrhea, flatulence, and abdominal pain [122]. AGIs block the enzymatic reaction particularly because of their nitrogen component. Thus, they must be present at the site of enzymatic action at the same time as the carbohydrates. Three AGIs are now in therapeutic use worldwide; acarbose isolated from culture filtrates of Actinoplanes, was first described by Schmidt in 1977 and introduced onto the market in 1990; miglitol, a semisynthetic derivative of 1-deoxynojirimycin, from Bacillus and Streptomyces spp; and voglibose, which is prepared from validamycin A, a product of Streptomyces hygroscopicus [84]. In Mexico, only acarbose is available.

While flavonoids and phenylpropanoids are well-known $\alpha$-glucosidase inhibitors, depsides, phthalides, 4-phenylcoumarins, chromenes, $\alpha$-pyrones, and sesquiterpene lactones are not. The most important AGIs isolated from Mexican plants are $\alpha$-pipitzol (5), $\beta$-pipitzol (6), 6-acetyl-5-hydroxy-2,2-dimethyl-2H-chromene (39), calein A (42), calein C (43), 3-(Z)-butylidenephthalide (171), perfoliatin A (175), amarisolide (213), and pedalitin (214), and the 4-phenylcoumarins 106 and 109 (Table 2). This ranking arose because these compounds showed in vivo and in vitro action. Some of them possessed other mechanisms as discussed later. Kinetic analysis indicated that 6-acetyl-5-hydroxy-2,2-dimethyl-2H-chromene (39) and calein C (43) behaved as noncompetititive and mixed $(\mathrm{Ki}$ of $0.13 \mathrm{~m})$ type inhibitors, respectively, against $S$. cerevisiae $\alpha$-glucosidase [28]. This behavior was consistent with the in silico predictions with AutoDock4, which revealed that 43 bound close to the catalytic site of the enzyme, with a Ki value of $0.30 \mu \mathrm{M}$ while compound 39 bound in regions different from the catalytic area, with a Ki value of $13 \mu \mathrm{M}$. 3-(Z)-Butylidenephthalide (171), was also characterized as noncompetitive inhibitor with a Ki of $4.86 \mathrm{mM}$ [67]. The 4-phenylcoumarins 106 and 109 were also good inhibitors of yeast $\alpha$-glucosidase, but their aglycones were most active [115]. Another unusual $\alpha$-glucosidase inhibitor was the sesquiterpene salvinine (26), which behaved as a mixed type of inhibitor and because its size and properties form an interesting molecule for optimization to increase its potency [22]. Perfoliatin (175) [68] amarisolide (213), pedalitin (214) [85] were not subjected to kinetic analysis but in silico analysis predicted that these compounds bind to yeast- $\alpha$-glucosidase at the same site than acarbose.

\subsection{Effect over Insulin Secretion}

Different types of compounds increase insulin secretion. The first group described were the sulphonylureas, SUs, which stimulate the $\beta$-cells of the pancreas to release insulin. SUs binds to 
the SU receptor (SUR), a subunit of the potassium ATP-dependent (KATP) channels in the $\beta$-cell membrane, which eventually blocks the potassium channels and facilitates the influx of $\mathrm{Ca}^{2+}$ into the cell, leading to membrane depolarization and subsequently insulin exocytosis. The main side effect is hypoglycemia; in Mexico, the most used SU is glibenclamide [123].

The glinides include drugs such as repaglinide (the only one available in Mexico), which belong to the group of nonsulfonylurea insulin secretagogues, with a rapid onset and reduced interval of action. They act by binding to the SUR1 receptor of the pancreatic $\beta$-cells (in a different site than SUs), they have less affinity for the receptor in comparison to SUs. Unfortunately, the glinides produce many adverse effects such as nausea, vomiting, diarrhea, constipation, gastrointestinal upsets, and abdominal pain. Due to their short duration of action, the associated hypoglycemia is much less recurrent than SUs [124].

Incretin-based medicines; after the intake of oral glucose, a phenomenon called incretin effect occurs, which increases insulin secretion up to $50-70 \%$. The incretin hormones, Glucagon-like peptide-1 (GLP-1) and the glucose-dependent insulinotropic polypeptide (GIP) are intestinal peptides released after ingestion of food; they augment the pancreatic islet function by increasing insulin release and suppressing the synthesis of glucagon. The incretin-based medications include two classes of drugs, dipeptidyl peptidase-4 (DPP-4) inhibitors and GLP-1 receptor agonists. Both medications diminished the glycemic abnormalities. The incretin hormones GLP-1 and GIP inhibited gastric emptying, decreased appetite and food intake, and reduced glucagon's secretion. The life span of GLP-1 is very short, as DPP-4 converts GLP-1 into an inactive form. While DPP-4 inhibitors increase the life span of the incretin hormones, the GLP1 agonists imitate the glucoregulatory actions of GLP-1 and diminish the release of glucagon, thus improving the glucose-dependent secretion of insulin. At the same time, common symptoms associated with the use of GLP-1 receptor agonists include gastrointestinal symptoms, mainly nausea and vomiting, headaches, reactions at the site of injection, and nasopharyngitis [125,126]. In Mexico, exenatide (a GLP1 agonist) is available as well as the DPP-4 inhibitor (sitagliptin).

Based on the reported experiments, a few molecules isolated from Mexican plants can increase insulin levels; the most common were again phenylpropanoids and flavonoids. The first group includes the phenylpropanoids $\rho$-coumaric acid (3) and caffeic acid (112). The relevant flavonoids were eupatilin (23) and jaceosidin (24) which increased insulin secretion with no specific mechanism; but with the involvement of $\mathrm{K}^{+}$-ATP sensitive and $\mathrm{Ca}^{2+}$-voltage-dependent channels, which play an important role in insulin secretion [21,22]. The flavonol kaempferol (46) restores PA-induced loss of $\beta$-cell mass and function through AMPK/mTOR-mediated autophagy. Finally, cinchonain 1b (204) induces insulin secretion in vitro and in vivo.

More unusual were 3-O- $\beta$-D-glucopyranosyl-23,24-dihydrocucurbitacin F (115), 5-O-D-glucopyranosyl7-3', $4^{\prime}$-triihydroxy-4-phenylcoumarin (109), 5-O-[ $\beta$-D-apiofuranosyl-(1 $\left.\rightarrow 6\right)-\beta$-D-glucopyranosyl]-7methoxy-3', 4'-dihydroxy-4-phenyl-coumarin (116) and other 4-phenylcoumarins, which increase insulin secretion in rats [55]. Compounds 109 and 116 stimulated AMPK phosphorylation in vitro in C2C12 myoblast cells. Thus, these compounds activate the AMPK pathway, which, in turn, could stimulate insulin secretion [127]. Based on these structures, Wang and collaborators in 2017 [128] synthesized a few substituted 4-phenylcoumarins derivatives analogs of compound 109; their pharmacological investigation showed that those 4-phenylcoumarins possessing adjacent 7,8-dihydroxy groups were equipotent to the standard drug glibenclamide as hypoglycemic agents in vivo. In addition, these compounds inhibited aldose reductase and advanced glycation end-product formation. Altogether, this shows the potential of 4-phenylcoumarins for the development of therapeutic agents for treating diabetes, and how products discovered during the investigation of Mexican hypoglycemic plants are useful as templates for the development of more active compounds [128]. The sesquiterpene lactone arglanin (25) was investigated as a hypoglycemic agent in Mexico for the first time. Its nonspecific mechanisms also involved $\mathrm{K}^{+}$-ATP sensitive and $\mathrm{Ca}^{2+}$-voltage-dependent channels [22]. Finally, the cyclitol L-chiro-inositol (14), is also a well-known hypoglycemic agent. 
Inositol derivatives (among them compound 14), have been reported to help the action of insulin stimulating glucose uptake in skeletal muscle cells, so they also work as insulin sensitizers [18,129].

\subsection{Insulin Sensitizers}

As mentioned above, T2D has two main components, insulin resistance and a progressive failure in insulin secretion. Insulin Resistance (IR) leads to a loss of response from the peripheral insulin target tissues (mainly the liver, adipose, and muscle tissues) to insulin. IR impairs the ability of the pancreatic cells to synthesize and secrete enough insulin to address the metabolic needs of the body. Insulin sensitizers help target cells in liver, skeletal muscle, and adipose tissue to respond properly to insulin, resulting in their ability to efficiently uptake and metabolize glucose [130].

Glitazones (TZDs) are insulin sensitizers used for treating T2D. TZDs are selective agonists of $\operatorname{PPAR} \gamma$, a transcription factor involved in the regulation of the expression of specific genes present in fat cells and other tissues. TZDs primarily act in adipose tissue where expression of PPAR $\gamma$ predominates. They interfere with the expression and release of mediators of IR (e.g., free fatty acids, adipocytokines, resistin, adiponectin) that originate in adipose tissue, thus resulting in improvement of insulin sensitivity in muscle and liver [131]. Treatment with TZDs might produce adverse hepatic, cardiovascular, osteological, and carcinogenic events [132]; therefore, TZDs were withdrawn for the market in several European countries; in Mexico, rosiglitazone is still available. Because of the importance of insulin sensitizers in the treatment of T2D, new-generation insulin sensitizers classified as direct PPAR $\gamma$ agonists, selective PPAR $\gamma$ modulators, and PPAR $\gamma$-sparing compounds are in development [130].

Some important molecules acting as insulin sensitizers, but with an unknown mechanism, isolated from Mexican plants are: Protocatechuic acid (1), catechin (2) oleanolic acid (70), and epicatechin (113), for these molecules, the HOMA has been calculated. Acacetin (21) and diosmetin (22) are PPAR agonists. Isorhamnetin (45) and quercetin (47) increase glucose uptake in skeletal muscle by activation of the JAK/STAT pathway, and CaMKK $\beta / A M P K$ and insulin signaling pathways, respectively. Kaempferitrin (169) inhibits GLUT4 mediated glucose uptake in differentiated 3T3-L1 cells by interfering with the insulin signaling pathway and by directly interacting with membrane GLUT4. $\beta$-sitosterol (34) attenuates the insulin receptor substrate-1 serine phosphorylation. However, it up-regulates RNA expression of IR and postreceptor insulin signaling molecules such as IRS-1, $\beta$-arrestin 2, Akt, AS160, and GLUT4 with a concomitant increase in the levels of IRS-1, p-IRS1-1, Akt, p-Akt, AS160, and p-AS160 compared with type-2 diabetic rats [118]. Finally, 5-O-[ $\beta$-D-apiofuranosyl-(1 $\rightarrow 6)-\beta$-D-glucopyranosyl]-7-methoxy-3' $4^{\prime}$-dihydroxy-4-phenyl-coumarin (116) stimulated ${ }^{3} \mathrm{H}$-deoxyglucose uptake in $\mathrm{C} 2 \mathrm{C} 12$ myoblasts cells after $18 \mathrm{~h}$ of incubation. The effect was like metformin and insulin and was concentration-dependent [59].

\subsection{Inhibitors of Hepatic Glucose Output (HGO)}

One important action of insulin is the signaling over the liver when there is not enough insulin or there is some degree of insulin resistance in the hepatic cell, the result is an augmentation of glucose output. The liver plays a crucial role in maintaining blood glucose levels during fasting by converting its stored glycogen to glucose (glycogenolysis) and by synthesizing glucose, mainly from pyruvate and amino acids (gluconeogenesis) [133].

In T2D subjects with mild to moderate fasting hyperglycemia (140-200 mg/dL), basal hepatic glucose production increases by $\sim 0.5 \mathrm{mg} / \mathrm{kg} \mathrm{min}$. Consequently, during the overnight sleeping hours $(22.00$ to $8.00 \mathrm{~h}$ ), the liver of an $80 \mathrm{~kg}$ diabetic individual with modest fasting hyperglycemia adds $35 \mathrm{~g}$ of glucose to the systemic circulation. In T2D, insulin resistance in the liver reflects hyperinsulinemia's failure to suppress gluconeogenesis, resulting in fasting hyperglycemia and decreased liver glycogen storage in the postprandial state. Increased hepatic glucose production occurs early during diabetes, although the increase is more obvious after the onset of insulin secretory abnormalities and insulin 
resistance in skeletal muscle. T2D is characterized by impaired glucose homeostasis partly due to abnormally elevated HGO [134].

Metformin, the main insulin sensitizer in use worldwide, acts by different mechanisms, diminishing the intestinal glucose absorption, increasing peripheral uptake and use of glucose, and lowering the hepatic synthesis of glucose [122]. Although metformin is an insulin sensitizer, its action over the HGO is also significant; metformin induces mild energy stress in the liver, leading to an increase in AMP concentration that allosterically inhibits the enzyme fructose-1,6-bisphosphatase-(FBP1) to lower HGO. This is a very important mechanism, as the subsequent increase in F-1,6-P2, will activate PK and increase glycolytic flux. Because AMP-inhibited FBP1, a rate-controlling enzyme in gluconeogenesis, it functions as a major contributor to the therapeutic action of metformin [135].

Although in the international literature, polyphenols like kaempferol or caffeic acid have been related to the blockage of the enzyme G6Pase, from Mexican plants, chlorogenic acid a well-characterized inhibitor of the G6Pase T1 translocase system [19]; thus, it can block HGO, has been reported. $\rho$-Coumaric acid (3) inhibits fructose-1,6-bisphosphatase, which also leads to the block of HGO; however, this mechanism has not been explored in molecules isolated from Mexican plants.

The limonoids 2-hydroxy-destigloyl-6-deoxyswietenine acetate (221), methyl-2-hydroxy-3- $\beta$ tigloyloxy-1-oxomeliac-8(30)-enate (223), and humilinolide $\mathrm{H}$ (228), isolated from $S$. humilis, inhibit also glucose-6-phosphatase, representing new leads for further exploration as HGO, agents. The complexity of their structure makes them good candidates for fragment-based drug discovery.

\section{Discussion}

T2D is an important health problem in many countries; Mexico is not an exception. Like in many developing countries, in Mexico the use of medicinal plants is a common practice, for these two main reasons, plants play an essential role in how the Mexican population treats T2D, this situation is beside the institutional medical attention. It is important to understand how these plants produce a hypoglycemic effect for future isolation of promissory molecules for the development of new hypoglycemic agents.

In the present manuscript, we document 86 molecules isolated from Mexican plants, intending to provide a necessary inventory for further studies. Almost half of these molecules are not common metabolites, with a narrow taxonomic distribution, which makes them more interesting as lead molecules. Some of the most complex molecules (i.e., the limonoids, cucurbitans, or the oligosaccharides) are good candidates for fragment-based drug discovery. The studies summarized in Tables 1 and 2 along with chemical informatics methods and network pharmacology provides useful information for the development of new phytopharmaceutical preparations. In addition, because some of these molecules are present in plants worldwide, Table 2 will be a useful reference for promoting the testing of these compounds in other targets, known or news, and a better insight into the already described mechanisms.

When hypoglycemic plants are studied it is imperative to set the goal of the study; one point is to prove if the plant has a hypoglycemic effect, which can explain the traditional use but another point is to escalate the study to produce a phytomedicine or a single isolated compound, like metformin. The fact that a plant possesses a hypoglycemic effect does not necessarily mean that it will be of clinical use; for this reason, it is essential to study single molecules in known and new pharmacological targets, aiming to have novel hypoglycemic agents of clinical relevance.

In recent years, the investigation of medicinal plants used to treat diabetes in Mexico has improved. However, we still need to achieve the final goal, contributing with a hypoglycemic agent or phytomedicines of significant clinical efficacy; we are just in the initial steps documenting hypoglycemic plants, and progressing in preclinical testing. The works have been narrowed in scope, both from the pharmacological and chemical point of view. The number and diversity of small molecules to address all the different binding sites in the complex biology of diabetes are still awaiting to be isolated from the plants in Table 1, and other plants yet to be discovered. The essential oils of these plants, plenty of small 
molecules suitable for the development of hypoglycemic agents remain unexplored. The constituents of the essential oils offer good prospects for drug discovery. These constituents meet most conditions required for good drug candidates and offer attractive opportunities for lead optimization or even fragment-based drug discovery. New technologies such as metabolomics can accelerate dereplication and identification of compounds with novel skeletons; routine incorporation of protein-metabolite interaction and cell-based assays, which require small amounts of samples are essential.

Most compounds in Table 1 require testing as glucose reabsorption inhibitors, incretin analogs, DDP4 blockers, bile acid sequestrants, or dopamine agonists. The effect of these molecules over gut microbiota also needs attention since these bacteria play an important role in the control of T2D. We consider essential to test these molecules as glucose reabsorption inhibitors in the kidney because many plants traditionally used for treating T2D are also employed to treat "Mal de Orin", an entity that people detect when you have urination problems; this type of plants augment the urine flux. The inhibition of hepatic glucose output is also an important target to assess. From there compounds with similar actions like metformin could upsurge.

A single molecule can have more than one mechanism of action. This might be targeting different proteins within the same (network pharmacology) or different (polypharmacology) signaling pathways In the context, of a botanical mixture, a pool of molecules, perhaps in low concentrations, acting by biochemical synergism can lead to the desired effect, hypoglycemic action, without the presence of a major highly bioactive compound. This has been the classic paradigm of phytotherapy. The advantages of dealing with polyvalent drugs are a decrease of drug-drug interactions, less cost for the patient to bear, increased adherence due to lower side effects, the possibility of treating concomitant diseases, just to mention a few. In this review, we found some examples of compounds possessing more than one mechanism. Thus, protocatechuic acid (1) is an insulin sensitizer and secretagogue. Quercetin (47) is an insulin sensitizer and secretagogue, as well as the inhibitor of $\alpha$-glucosidases. Epicatechin (113) inhibits $\alpha$-glucosidase and behaves as an insulin sensitizer. Kaempferol (46) inhibits hepatic gluconeogenesis, is an insulin sensitizer and inhibits $\alpha$-glucosidases. Caffeic acid (112) induces insulin secretion, decreases hepatic glucose output, inhibits alpha glucosidases, and is an insulin sensitizer. Furthermore, 2-Hydroxy-destigloyl-6-deoxyswietenine acetate (221) stimulates insulin secretion due to a partial blockade of $\mathrm{K}^{+}$-ATP channels, and a serotonergic modulation on 5-HT2 receptors inhibited hepatic glucose-6-phosphatase, and stimulated muscle glucose uptake and basal oxygen consumption in muscle cells [91]. The 4-phenylcoumaris affects glucose absorption, insulin secretion, and glucose utilization. With these examples, we want to remark the importance of testing 86 described compounds over different action mechanisms.

\section{Materials and Methods}

This study was performed based on the Preferred Reporting Items for Systematic Review and Meta-Analysis (PRISMA) [136]. To obtain pertinent literature, without author bias, peer-reviewed research articles were obtained from the following databases: PubMed, MEDLINE, EMBASE, SCOPUS, SciFinder, and Clarivate Analytics. Inclusion criteria were studies reporting the hypoglycemic effect of Mexican medicinal plants, and at least one pure compound was isolated and selected.

\section{Conclusions}

The use of medicinal plants to manage diabetes is an overwhelming reality that requires being set into the correct health care perspective. Indeed, these plants will keep providing promissory agents for the development of new antidiabetic drugs or phytotherapeutic products. In this review, we summarize new and known hypoglycemic agents from the reported Mexican hypoglycemic plants. These compounds represent only a small fraction of the chemical space of Mexican Medicinal plants. Some of the compounds' scaffolds are common, in particular those of the phenylpropanoids and flavonoids. Among the terpenoids and steroids, the ursanes and stigmastanes are widespread in nature, while the remaining terpenoids are less common and restricted to some genus of some family 
plants. Finally, the other aromatic compounds and the resin glycosides are also limited to a few vegetal species. Except for the flavonoids and phenylpropanoids, the hypoglycemic properties and/or the chemical structures of most compounds were discovered in Mexico, following an ethnopharmacological hypothesis. Their mechanisms of actions involved inhibition of $\alpha$-glucosidase, insulin secretion or sensitization, and/or inhibition of hepatic glucose output. Some of the less common compounds are multitarget which makes them attractive for drug development.

Author Contributions: S.M.E.-R.; Performed the bibliographic research summarized in tables and figures. R.M. and A.A.-C., equally contributed to writing the manuscript. A.A.-C. envisioned the review. All authors have read and agreed to the published version of the manuscript.

Funding: This project was partially sponsored by DGAPA (PAPIIT IN226719, PAPIIT IN 217320) and CONACyT CB A1-S-11226.

Conflicts of Interest: The authors declare no conflict of interest.

\section{References}

1. American Diabetes Association 2. Classification and Diagnosis of Diabetes: Standards of Medical Care in Diabetes-2020. Diabetes Care 2019, 43, S14-S31. [CrossRef]

2. Carracher, A.M.; Marathe, P.H.; Close, K.L. International Diabetes Federation 2017. J. Diabetes 2018, 10, 353-356. [CrossRef] [PubMed]

3. Andrade-Cetto, A.; Becerra-Jiménez, J.; Martínez-Zurita, E.; Ortega-Larrocea, M.P.; Heinrich, M. Disease-Consensus Index as a tool of selecting potential hypoglycemic plants in Chikindzonot, Yucatán, México. J. Ethnopharmacol. 2006, 107, 199-204. [CrossRef]

4. Andrade-Cetto, A.; Heinrich, M. Mexican plants with hypoglycaemic effect used in the treatment of diabetes. J. Ethnopharmacol. 2005, 99, 325-348. [CrossRef]

5. Cruz, E.C.; Andrade-Cetto, A. Ethnopharmacological field study of the plants used to treat type 2 diabetes among the Cakchiquels in Guatemala. J. Ethnopharmacol. 2015, 159, 238-244. [CrossRef]

6. Andrade-Cetto, A. Ethnobotanical study of the medicinal plants from Tlanchinol, Hidalgo, México. J. Ethnopharmacol. 2009, 122, 163-171. [CrossRef]

7. Pěsíc, M. Development of Natural Product Drugs in A Sustainable Manner. GDSR. 2015. Available online: https://sustainabledevelopment.un.org/content/documents/6544118_Pesic_ Developmentofnaturalproductdrugsinasustainablemanner.pdf (accessed on 10 June 2020).

8. Bauer, A.; Broenstrup, M. Industrial natural product chemistry for drug discovery and development. Nat. Prod. Rep. 2014, 31, 35-60. [CrossRef]

9. World Health Organisation (WHO) Diabetes. Available online: https://www.who.int/health-topics/diabetes\# tab=tab_3 (accessed on 10 June 2020).

10. American Diabetes Association 5. Lifestyle management: Standards of medical care in diabetes-2019. Diabetes Care 2018, 42, S46-S60. [CrossRef]

11. White, J.R. A Brief history of the development of diabetes medications. Diabetes Spectr. 2014, $27,82-86$. [CrossRef]

12. Rodríguez-Méndez, A.J.; Carmen-Sandoval, W.; Lomas-Soria, C.; Guevara-Gonzalez, R.G.; Reynoso-Camacho, R.; Villagran-Herrera, M.E.; Salazar-Olivo, L.A.; Torres-Pacheco, I.; Feregrino-Perez, A.A. Timbe (Acaciella angustissima) pods extracts reduce the levels of glucose, insulin and improved physiological parameters, hypolipidemic effect, oxidative stress and renal damage in streptozotocin-induced diabetic rats. Molecules 2018, 23, 2812. [CrossRef]

13. Martínez, A.L.; Madariaga-Mazón, A.; Rivero-Cruz, I.; Bye, R.; Mata, R. Antidiabetic and antihyperalgesic effects of a decoction and compounds from Acourtia thurberi. Planta Med. 2016, 83, 534-544. [CrossRef]

14. Wiedenfeld, H.; Andrade-Cetto, A. Pyrone glycosides from Acosmium panamense (Benth.) Yacovlev. Zeitschrift für Naturforschung C 2003, 58, 637-639. [CrossRef] [PubMed]

15. Andrade-Cetto, A.; Wiedenfeld, H. Hypoglycemic effect of Acosmium panamense bark on streptozotocin diabetic rats. J. Ethnopharmacol. 2004, 90, 217-220. [CrossRef] [PubMed] 
16. Perez, G.R.M.; Perez, G.S.; Zavala, M.A.; Perez, G.S.C. Effect of Agarista mexicana and Verbesina persicifolia on blood glucose level of normoglycaemic and alloxan-diabetic mice and rats. Phytother. Res. 1996, 10, 351-353. [CrossRef]

17. Perez, G.R.M.; Solis, R.V. Triterpenes from Agarista mexicana as potential antidiabetic agents. Phytother. Res. 2002, 16, 55-58. [CrossRef] [PubMed]

18. Bustos-Brito, C.; Andrade-Cetto, A.; Giraldo-Aguirre, J.D.; Moreno-Vargas, A.D.; Quijano, L. Acute hypoglycemic effect and phytochemical composition of Ageratina petiolaris. J. Ethnopharmacol. 2016, 185, 341-346. [CrossRef]

19. Mata-Torres, G.; Andrade-Cetto, A.; Espinoza-Hernández, F.A.; Cárdenas-Vázquez, R. Hepatic glucose output inhibition by Mexican plants used in the treatment of Type 2 Diabetes. Front. Pharmacol. 2020, 11, 11. [CrossRef]

20. Calzada, F.; Solares-Pascasio, J.I.; Ordoñez-Razo, R.M.; Velázquez, C.; Barbosa, E.; García-Hernández, N.; Mendez-Luna, D.; Correa-Basurto, J. Antihyperglycemic Activity of the Leaves from Annona cherimola Miller and Rutin on Alloxan-induced Diabetic Rats. Pharmacogn. Res. 2017, 9, 1-6. [CrossRef] [PubMed]

21. Juárez-Reyes, K.; Brindis, F.; Medina-Campos, O.N.; Pedraza-Chaverri, J.; Bye, R.; Linares, E.; Mata, R. Hypoglycemic, antihyperglycemic, and antioxidant effects of the edible plant Anoda cristata. J. Ethnopharmacol. 2015, 161, 36-45. [CrossRef]

22. Anaya-Eugenio, G.D.; Rivero-Cruz, I.; Rivera-Chávez, J.; Mata, R. Hypoglycemic properties of some preparations and compounds from Artemisia ludoviciana Nutt. J. Ethnopharmacol. 2014, 155, 416-425. [CrossRef]

23. García-Galicia, M.C.; Burgueño-Tapia, E.; Romero-Rojas, A.; García-Zebadúa, J.C.; Cornejo-Garrido, J.; Ordaz-Pichardo, C. Anti-hyperglycemic effect, inhibition of inflammatory cytokines expression, and histopathology profile in streptozotocin-induced diabetic rats treated with Arracacia tolucensis aerial-parts extracts. J. Ethnopharmacol. 2014, 152, 91-98. [CrossRef] [PubMed]

24. Palacios-Espinosa, F.; Déciga-Campos, M.; Mata, R. Antinociceptive, hypoglycemic and spasmolytic effects of Brickellia veronicifolia. J. Ethnopharmacol. 2008, 118, 448-454. [CrossRef] [PubMed]

25. Perez, G.R.M.; Cervantes, C.H.; Zavala, S.M.A.; Sanchez, A.J.; Perez, G.S.; Perez, G.C. Isolation and hypoglycemic activity of 5, 7,3'-trihydroxy-3,6,4'-trimethoxyflavone from Brickellia veronicaefolia. Phytomedicine 2000, 7, 25-29. [CrossRef]

26. Andrade-Cetto, A.; Medina-Hernández, A.E.B. Hypoglycemic effect of Bromelia plumieri (E. Morren) L.B. Sm., leaves in STZ-NA-induced diabetic rats. Front. Pharmacol. 2013, 4. [CrossRef]

27. Escandón-Rivera, S.M.; Andrade-Cetto, A.; Sánchez-Villaseñor, G. Phytochemical composition and chronic hypoglycemic effect of bromelia karatas on STZ-NA-induced diabetic rats. Evid. Based Complementary Altern. Med. 2019, 2019, 1-9. [CrossRef]

28. Escandón-Rivera, S.M.; González-Andrade, M.; Bye, R.; Linares, E.; Navarrete, A.; Mata, R. $\alpha$-Glucosidase inhibitors from Brickellia cavanillesii. J. Nat. Prod. 2012, 75, 968-974; reprint in J. Nat. Prod. 2017, 80, 233. [CrossRef]

29. Escandón-Rivera, S.M.; Pérez-Vásquez, A.; Navarrete, A.; Hernández, M.; Linares, E.; Bye, R.; Mata, R. Anti-hyperglycemic activity of major compounds from Calea ternifolia. Molecules 2017, 22, 289. [CrossRef]

30. Andrade-Cetto, A.; Wiedenfeld, H. Hypoglycemic effect of Cecropia obtusifolia on streptozotocin diabetic rats. J. Ethnopharmacol. 2001, 78, 145-149. [CrossRef]

31. Revilla-Monsalve, M.C.; Andrade-Cetto, A.; Palomino-Garibay, M.A.; Wiedenfeld, H.; Islas-Andrade, S. Hypoglycemic effect of Cecropia obtusifolia Bertol aqueous extracts on type 2 diabetic patients. J. Ethnopharmacol. 2007, 111, 636-640. [CrossRef]

32. Andrade-Cetto, A.; Becerra-Jiménez, J.; Cárdenas-Vázquez, R. Alfa-glucosidase-inhibiting activity of some Mexican plants used in the treatment of type 2 diabetes. J. Ethnopharmacol. 2008, 116, 27-32. [CrossRef]

33. Alonso-Castro, A.J.; Miranda-Torres, A.C.; González-Chávez, M.M.; Salazar-Olivo, L.A. Cecropia obtusifolia Bertol and its active compound, chlorogenic acid, stimulate 2-NBDglucose uptake in both insulin-sensitive and insulin-resistant 3T3 adipocytes. J. Ethnopharmacol. 2008, 120, 458-464. [CrossRef]

34. Sánchez-Salgado, J.; Ortiz-Andrade, R.; Aguirre-Crespo, F.; Vergara-Galicia, J.; León-Rivera, I.; Montes, S.; Villalobos-Molina, R.; Estrada-Soto, S. Hypoglycemic, vasorelaxant and hepatoprotective effects of Cochlospermum vitifolium (Willd.) Sprengel: A potential agent for the treatment of metabolic syndrome. J. Ethnopharmacol. 2007, 109, 400-405. [CrossRef] [PubMed] 
35. Ortiz-Andrade, R.; Torres-Piedra, M.; Sánchez-Salgado, J.C.; García-Jiménez, S.; Villalobos-Molina, R.; Ibarra-Barajas, M.; Gallardo-Ortiz, I.; Estrada-Soto, S. Acute and sub-chronic effects of Cochlospermum vitifolium in blood glucose levels in normoglycemic and STZ-nicotinamide-induced diabetic rats. Rev. Latinoam. Quim. 2009, 37, 122-132.

36. Brindis, F.; González-Andrade, M.; González-Trujano, M.; Estrada-Soto, S.; Villalobos-Molina, R. Postprandial glycaemia and inhibition of $\alpha$-glucosidase activity by aqueous extract from Coriandrum sativum. Nat. Prod. Res. 2014, 28, 2021-2025. [CrossRef] [PubMed]

37. Acosta-Patiño, J.; Jiménez-Balderas, E.; Juárez-Oropeza, M.; Diaz-Zagoya, J. Hypoglycemic action of Cucurbita ficifolia on Type 2 diabetic patients with moderately high blood glucose levels. J. Ethnopharmacol. 2001, 77, 99-101. [CrossRef]

38. Alarcon-Aguilar, F.; Hernandez-Galicia, E.; Campos-Sepulveda, A.E.; Xolalpa-Molina, S.; Rivas-Vilchis, J.F.; Vazquez-Carrillo, L.I.; Roman-Ramos, R. Evaluation of the hypoglycemic effect of Cucurbita ficifolia Bouché (Cucurbitaceae) in different experimental models. J. Ethnopharmacol. 2002, 82, 185-189. [CrossRef]

39. Díaz-Flores, M.; Angeles-Mejia, S.; Baiza-Gutman, L.; Medina-Navarro, R.; Hernandez-Saavedra, D.; Ortega-Camarillo, C.; Roman-Ramos, R.; Cruz, M.; Alarcon-Aguilar, F. Effect of an aqueous extract of Cucurbita ficifolia Bouché on the glutathione redox cycle in mice with STZ-induced diabetes. J. Ethnopharmacol. 2012, 144, 101-108. [CrossRef]

40. Pérez, M.E.M.; Ortega-Camarillo, C.; Escobar-Villanueva, M.D.C.; Blancas-Flores, G.; Alarcon-Aguilar, F.; Flores-Blancas, G. Cucurbita ficifolia Bouché increases insulin secretion in RINm5F cells through an influx of Ca2+ from the endoplasmic reticulum. J. Ethnopharmacol. 2016, 188, 159-166. [CrossRef]

41. Jessica, G.G.; Mario, G.L.; Alejandro, Z.; Cesar, A.P.J.; Ivan, J.V.E.; Ruben, R.R.; Javier, A.-A.F. Chemical characterization of a hypoglycemic extract from Cucurbita ficifolia bouche that induces liver glycogen accumulation in diabetic mice. Afr. J. Tradit. Complement. Altern. Med. 2017, 14, 218-230. [CrossRef]

42. Wiedenfeld, H.; Andrade-Cetto, A.; Amador, C.P. Flavonol glycosides from Equisetum myriochaetum. Biochem. Syst. Ecol. 2000, 28, 395-397. [CrossRef]

43. Revilla, M.C.; Andrade-Cetto, A.; Islas, S.; Wiedenfeld, H. Hypoglycemic effect of Equisetum myriochaetum aerial parts on type 2 diabetic patients. J. Ethnopharmacol. 2002, 81, 117-120. [CrossRef]

44. Cetto, A.A.; Wiedenfeld, H.; Revilla, M.C.; Sergio, I.A. Hypoglycemic effect of Equisetum myriochaetum aerial parts on streptozotocin diabetic rats. J. Ethnopharmacol. 2000, 72, 129-133. [CrossRef]

45. Narváez-Mastache, J.M.; Garduño-Ramírez, M.L.; Alvarez, L.; Delgado, G. Antihyperglycemic Activity and Chemical Constituents of Eysenhardtia platycarpa. J. Nat. Prod. 2006, 69, 1687-1691. [CrossRef]

46. Narváez-Mastache, J.M.; Soto, C.; Delgado, G. Antioxidant evaluation of eysenhardtia species (fabaceae): Relay synthesis of 3-O-acetyl-11 $\alpha, 12 \alpha$-epoxy-oleanan-28,13 $\beta$-olide isolated from E. platycarpa and Its protective effect in experimental diabetes. Biol. Pharm. Bull. 2007, 30, 1503-1510. [CrossRef] [PubMed]

47. Pérez, R.M.; Ocegueda, A.Z.; Muñoz, L.J.L.; Avila, A.J.G.; Morrow, W.W. A study of the hypoglucemic effect of some Mexican plants. J. Ethnopharmacol. 1984, 12, 253-262. [CrossRef]

48. Pérez, G.R.M.; Baez, E.G. Evaluation of antidiabetic, antioxidant and antiglycating activities of the Eysenhardtia polystachya. Pharmacogn. Mag. 2014, 10, S404-S418. [CrossRef]

49. Pérez-Gutiérrez, R.M.; Garcia, C.A.H.; Muñiz-Ramírez, A. Properties of flavonoids isolated from the bark of eysenhardtia polystachya and their effect on oxidative stress in streptozotocin-induced diabetes mellitus in mice. Oxid. Med. Cell. Longev. 2016, 2016, 9156510. [CrossRef] [PubMed]

50. Pérez, G.R.M.; Garcia, C.A.H.; Mota, F.J.M.; Grcia, G.A.H. Dihydrochalcones from the bark of Eysenhardtia polystachya inhibits formation of advanced glycation end products at multiple stages in vitro studies. J. Pharm. Pharmacol. 2017, 1, 1-24. [CrossRef]

51. Pérez-Gutiérrez, R.M.; Garcia, C.A.H.; Carrera, S.P.P.; Muñiz-Ramírez, A.; Flores, J.M.M.; Flores-Valle, S.O. $3^{\prime}$-O- $\beta$-d-glucopyranosyl- $\alpha, 4,2^{\prime}, 4^{\prime}, 6^{\prime}$-pentahydroxy-dihydrochalcone, from bark of Eysenhardtia polystachya prevents diabetic nephropathy via inhibiting protein glycation in STZ-nicotinamide induced diabetic mice. Molecules 2019, 24, 1214. [CrossRef] [PubMed]

52. Pérez-Vásquez, A.; Castillejos-Ramírez, E.; Cristians, S.; Mata, R. Development of a UHPLC-PDA method for the simultaneous quantification of 4-phenylcoumarins and chlorogenic acid in Exostema caribaeum Stem Bark. J. Nat. Prod. 2014, 77, 516-520. [CrossRef] 
53. Andrade-Cetto, A.; Escandón-Rivera, S.; Garcia-Luna, V. Hypoglycemic effect of Hamelia patens Jacq., aerial part in STZ-NA-induced diabetic rats. Pharmacologyonline 2015, 3, 6569. Available online: https://pharmacologyonline.silae.it/files/archives/2015/vol3/PhOL_2015_3_A010_10_21_ Cetto_3_65_69.pdf (accessed on 10 June 2020).

54. Rugerio-Escalona, C.; Ordaz-Pichardo, C.; Becerra-Martinez, E.; Cruz-López, M.D.C.; López, V.E.L.Y.; Mendieta, A.; Maldonado-Mendoza, I.E.; Montejo, F.E.J. “diabetes and metabolism disorders medicinal plants: A glance at the past and a look to the future 2018": Antihyperglycemic activity of Hamelia patens Jacq. extracts. Evid. Based Complementary Altern. Med. 2018, 2018, 1-9. [CrossRef]

55. Guerrero-Analco, J.; Medina-Campos, O.; Brindis, F.; Bye, R.; Pedraza-Chaverri, J.; Navarrete, A.; Mata, R. Antidiabetic properties of selected Mexican copalchis of the Rubiaceae family. Phytochemistry 2007, 68, 2087-2095. [CrossRef] [PubMed]

56. Cristians, S.; Guerrero-Analco, J.A.; Pérez-Vásquez, A.; Palacios-Espinosa, F.; Ciangherotti, C.; Bye, R.; Mata, R. Hypoglycemic activity of extracts and compounds from the leaves of Hintonia standleyana and $H$. latiflora: Potential alternatives to the use of the stem bark of these species (1). J. Nat. Prod. 2009, 72, 408-413. [CrossRef] [PubMed]

57. Rivera-Chávez, J.; González-Andrade, M.; González, M.D.C.; Glenn, A.E.; Mata, R. Thielavins A, J and K: $\alpha$-Glucosidase inhibitors from MEXU 27095, an endophytic fungus from Hintonia latiflora. Phytochemistry 2013, 94, 198-205. [CrossRef]

58. Cristians, S.; Mata, R.; Bye, R. Phenological and geographical influence in the concentration of selected bioactive 4-phenylcoumarins and chlorogenic acid in Hintonia latiflora leaves. J. Ethnopharmacol. 2014, 152, 308-313. [CrossRef]

59. Guerrero-Analco, J.A.; Hersch-MartInez, P.; Pedraza-Chaverri, J.; Navarrete, A.; Mata, R. Antihyperglycemic effect of constituents from Hintonia standleyana in streptozotocin-induced diabetic rats. Planta Med. 2005, 71, 1099-1105. [CrossRef]

60. Alarcon-Aguilar, F.; Campos-Sepulveda, A.; Xolalpa-Molina, S.; Hernandez-Galicia, E.; Roman-Ramos, R. Hypoglycaemic activity of Ibervillea sonorae roots in healthy and diabetic mice and rats. Pharm. Biol. 2002, 40, 570-575. [CrossRef]

61. Alarcon-Aguilar, F.; Calzada-Bermejo, F.; Hernandez-Galicia, E.; Ruiz-Angeles, C.; Roman-Ramos, R. Acute and chronic hypoglycemic effect of Ibervillea sonorae root extracts-II. J. Ethnopharmacol. 2005, 97, 447-452. [CrossRef]

62. Hernández-Galicia, E.; Calzada, F.; Roman-Ramos, R.; Alarcón-Aguilar, F. Monoglycerides and fatty acids from Ibervillea sonorae root: Isolation and hypoglycemic activity. Planta Med. 2007, 73, 236-240. [CrossRef] [PubMed]

63. Rivera-Ramírez, F.; Escalona-Cardoso, G.N.; Garduño-Siciliano, L.; Galaviz-Hernández, C.; Paniagua-Castro, N. Antiobesity and hypoglycaemic effects of aqueous extract of Ibervillea sonorae in mice fed a high-fat diet with fructose. J. Biomed. Biotechnol. 2011, 2011, 1-6. [CrossRef] [PubMed]

64. Zapata-Bustos, R.; Alonso-Castro, A.J.; Gomez-Sanchez, M.; Salazar-Olivo, L.A. Ibervillea sonorae (Cucurbitaceae) induces the glucose uptake in human adipocytes by activating a PI3K-independent pathway. J. Ethnopharmacol. 2014, 152, 546-552. [CrossRef] [PubMed]

65. Rosas-Ramirez, D.; Escandón-Rivera, S.M.; Pereda-Miranda, R. Morning glory resin glycosides as $\alpha$-glucosidase inhibitors: In vitro and in silico analysis. Phytochemistry 2018, 148, 39-47. [CrossRef] [PubMed]

66. Ortiz-Andrade, R.; Cabañas-Wuan, A.; Arana-Argáez, V.E.; Alonso-Castro, A.J.; Zapata-Bustos, R.; Salazar-Olivo, L.A.; Domínguez, F.; Chávez, M.; Carranza-Álvarez, C.; García-Carrancá, A. Antidiabetic effects of Justicia spicigera Schltdl (Acanthaceae). J. Ethnopharmacol. 2012, 143, 455-462. [CrossRef]

67. Brindis, F.; Rodríguez, R.; Bye, R.; González-Andrade, M.; Mata, R.; Rodrıguez, R. (Z)-3-Butylidenephthalide from Ligusticum porteri, an $\alpha$-glucosidase Inhibitor. J. Nat. Prod. 2011, 74, 314-320. [CrossRef]

68. Flores-Bocanegra, L.; Torres-Colín, R.; González-Andrade, M.; Calderón, J.S.; Mata, R. In vivo and in vitro $\alpha$-glucosidase inhibitory activity of perfoliatin a from Melampodium Perfoliatum. Nat. Prod. Commun. 2019, 14, 5-6. [CrossRef]

69. Andrade-Cetto, A.; Martínez-Zurita, E.; Wiedenfeld, H. Hypoglycemic effect of Malmea depressa root on streptozotocin diabetic rats. J. Ethnopharmacol. 2005, 100, 319-322. [CrossRef] 
70. Andrade-Cetto, A.; Martínez-Zurita, E.; Soto-Constantino, A.; Revilla-Monsalve, C.; Wiedenfeld, H. Chronic hypoglycemic effect of Malmea depressa root on n5-streptozotocin diabetic rats. J. Ethnopharmacol. 2008, 116, 358-362. [CrossRef]

71. Andrade-Cetto, A. Inhibition of gluconeogenesis by Malmea depressa root. J. Ethnopharmacol. 2011, 137, 930-933. [CrossRef]

72. Andrade-Cetto, A.; Wiedenfeld, H. Anti-hyperglycemic effect of Opuntia streptacantha Lem. J. Ethnopharmacol. 2011, 133, 940-943. [CrossRef]

73. Becerra-Jiménez, J.; Andrade-Cetto, A. Effect of Opuntia streptacantha Lem. on alpha-glucosidase activity. J. Ethnopharmacol. 2012, 139, 493-496. [CrossRef] [PubMed]

74. Alarcon-Aguilar, F.; Roman-Ramos, R.; Jiménez-Estrada, M.; Reyes-Chilpa, R.; Gonzalez-Paredes, B.; Flores-Saenz, J. Effects of three Mexican medicinal plants (Asteraceae) on blood glucose levels in healthy mice and rabbits. J. Ethnopharmacol. 1997, 55, 171-177. [CrossRef]

75. Alarcon-Aguilar, F.; Jiménez-Estrada, M.; Reyes-Chilpa, R.; Gonzalez-Paredes, B.; Contreras-Weber, C.; Roman-Ramos, R. Hypoglycemic activity of root water decoction, sesquiterpenoids, and one polysaccharide fraction from Psacalium decompositum in mice. J. Ethnopharmacol. 2000, 69, 207-215. [CrossRef]

76. Estrada, M.J.; Merino-Aguilar, H.; Lopez-Fernandez, A.; Rojano-Vilchis, N.A.; Roman-Ramos, R.; Alarcon-Aguilar, F. Chemical characterization and evaluation of the hypoglycemic effect of fructooligosaccharides from Psacalium decompositum. J. Complement. Integr. Med. 2011, 8, 8. [CrossRef]

77. Merino-Aguilar, H.; Arrieta-Baez, D.; Estrada, M.J.; Magos-Guerrero, G.; Hernández-Bautista, R.J.; Susunaga-Notario, A.D.C.; Almanza-Pérez, J.C.; Blancas-Flores, G.; Roman-Ramos, R.; Alarcon-Aguilar, F. Effect of fructooligosaccharides fraction from Psacalium decompositum on inflammation and dyslipidemia in rats with fructose-induced obesity. Nutrients 2014, 6, 591-604. [CrossRef]

78. De Rodríguez, D.J.; García-Hernández, L.; Rocha-Guzmán, N.E.; Moreno-Jiménez, M.; Rodríguez-García, R.; Díaz-Jiménez, M.; Flores-López, M.L.; Villarreal-Quintanilla, J.; Peña-Ramos, F.; Carrillo-Lomelí, D. Hypoglycemic and anti-inflammatory effects of Psacalium paucicapitatum corms infusions. Ind. Crop. Prod. 2017, 107, 482-488. [CrossRef]

79. Ramírez-Espinosa, J.J.; Rios, M.Y.; Martinez, S.L.; López-Vallejo, F.; Medina-Franco, J.L.; Paoli, P.; Camici, G.; Navarrete-Vázquez, G.; Ortiz-Andrade, R.; Estrada-Soto, S. Antidiabetic activity of some pentacyclic acid triterpenoids, role of PTP-1B: In vitro, in silico, and in vivo approaches. Eur. J. Med. Chem. 2011, 46, 2243-2251. [CrossRef]

80. López-Martinez, S.; Navarrete-Vázquez, G.; Estrada-Soto, S.; Leon, I.; Rios, M.Y. Chemical constituents of the hemiparasitic plant Phoradendron brachystachyum DC Nutt (Viscaceae). Nat. Prod. Res. 2013, 27, 130-136. [CrossRef]

81. Ramírez-Espinosa, J.J.; García-Jimenez, S.; Rios, M.Y.; Medina-Franco, J.L.; López-Vallejo, F.; Webster, S.P.; Binnie, M.; Ibarra-Barajas, M.; Ortiz-Andrade, R.; Estrada-Soto, S. Antihyperglycemic and sub-chronic antidiabetic actions of morolic and moronic acids, in vitro and in silico inhibition of 11 $\beta$-HSD 1. Phytomedicine 2013, 20, 571-576. [CrossRef] [PubMed]

82. Andrade-Cetto, A.; Mares, M.L.R. Hypoglycemic effect of the Rhizophora mangle cortex on STZ-NA-induced diabetic rats. Pharmacologyonline 2012, 3, 1-5. Available online: https://pharmacologyonline.silae.it/files/ archives/2012/vol3/PhOL_2012_3_A001_004_Cetto.pdf (accessed on 10 June 2020).

83. Andrade-Cetto, A.; Escandón-Rivera, S.M.; Torres-Valle, G.M.; Quijano, L. Phytochemical composition and chronic hypoglycemic effect of Rhizophora mangle cortex on STZ-NA-induced diabetic rats. Rev. Bras. Farm. 2017, 27, 744-750. [CrossRef]

84. Andrade-Cetto, A.; Cabello-Hernández, C.A.; Cárdenas-Vázquez, R. Alpha-glucosidase inhibiting activity of five Mexican plants used in the treatment of type 2 diabetes. Pharmacologyonline 2015, 1, 67-71. Available online: https://pharmacologyonline.silae.it (accessed on 10 June 2020).

85. Flores-Bocanegra, L.; González-Andrade, M.; Bye, R.; Linares, E.; Mata, R. $\alpha$-Glucosidase Inhibitors from Salvia circinata. J. Nat. Prod. 2017, 80, 1584-1593. [CrossRef]

86. Amaro, C.A.B.; González-Cortazar, M.; Herrera-Ruiz, M.; Roman-Ramos, R.; Aguilar-Santamaría, L.; Tortoriello-Garcia, J.; Jimenez-Ferrer, I. Hypoglycemic and hypotensive activity of a root extract of Smilax aristolochiifolia, standardized on N-trans-feruloyl-tyramine. Molecules 2014, 19, 11366-11384. [CrossRef] 
87. Pérez-Nájera, V.C.; Gutiérrez-Uribe, J.A.; Antunes-Ricardo, M.; Hidalgo-Figueroa, S.; Del-Toro-Sánchez, C.L.; Salazar-Olivo, L.A.; Cervantes, E.L. Smilax aristolochiifolia root extract and its compounds chlorogenic acid and astilbin inhibit the activity of $\alpha$-amylase and $\alpha$-glucosidase enzymes. Evid. Based Complementary Altern. Med. 2018, 2018, 6247306. [CrossRef]

88. Andrade-Cetto, A. Hypoglycemic effect of Smilax moranensis root on N5-STZ diabetic rats. Pharmacologyonline 2011, 1, 111-115. Available online: https://pharmacologyonline.silae.it/files/newsletter/2011/vol1/013.cettorev. pdf (accessed on 10 June 2020).

89. Romo-Pérez, A.; Escandón-Rivera, S.M.; Andrade-Cetto, A. Chronic hypoglycemic effect and phytochemical composition of Smilax moranensis roots. Rev. Bras. Farm. 2019, 29, 246-253. [CrossRef]

90. Ovalle-Magallanes, B.; Medina-Campos, O.N.; Pedraza-Chaverri, J.; Mata, R. Hypoglycemic and antihyperglycemic effects of phytopreparations and limonoids from Swietenia humilis. Phytochemistry 2015, 110, 111-119. [CrossRef]

91. Ovalle-Magallanes, B.; Déciga-Campos, M.; Mata, R. Antihyperalgesic activity of a mexicanolide isolated from Swietenia humilis extract in nicotinamide-streptozotocin hyperglycemic mice. Biomed. Pharmacother. 2017, 92, 324-330. [CrossRef]

92. Ovalle-Magallanes, B.; Navarrete, A.; Haddad, P.S.; Tovar, A.R.; Noriega, L.G.; Tovar-Palacio, C.; Mata, R. Multi-target antidiabetic mechanisms of mexicanolides from Swietenia humilis. Phytomedicine 2019, 58, 152891. [CrossRef]

93. Aguilar-Santamaría, L.; Ramirez, G.; Nicasio, P.; Alegría-Reyes, C.; Herrera-Arellano, A. Antidiabetic activities of Tecoma stans (L.) Juss. ex Kunth. J. Ethnopharmacol. 2009, 124, 284-288. [CrossRef] [PubMed]

94. Ramirez, G.; Zamilpa, A.; Zavala, M.; Perez, J.; Morales, D.; Tortoriello-Garcıa, J.; Guillermo, R.; Alejandro, Z.; Miguel, Z.; Julia, P.; et al. Chrysoeriol and other polyphenols from Tecoma stans with lipase inhibitory activity. J. Ethnopharmacol. 2016, 185, 1-8. [CrossRef] [PubMed]

95. Parra-Naranjo, A.; Delgado-Montemayor, C.; Fraga-López, A.; Castañeda-Corral, G.; Salazar-Aranda, R.; Acevedo-Fernández, J.J.; De Torres, N.W. Acute hypoglycemic and antidiabetic effect of teuhetenone a isolated from Turnera diffusa. Molecules 2017, 22, 599. [CrossRef]

96. Semaming, Y.; Kukongviriyapan, U.; Kongyingyoes, B.; Thukhammee, W.; Pannangpetch, P. Protocatechuic acid restores vascular responses in rats with chronic diabetes induced by streptozotocin. Phytother. Res. 2015, 30, 227-233. [CrossRef]

97. Scazzocchio, B.; Varì, R.; Filesi, C.; D’Archivio, M.; Santangelo, C.; Giovannini, C.; Iacovelli, A.; Silecchia, G.; Volti, G.L.; Galvano, F. Cyanidin-3-O- $\beta$-glucoside and protocatechuic acid exert insulin-like effects by upregulating PPAR $\gamma$ activity in human omental adipocytes. Diabetes 2011, 60, 2234-2244. [CrossRef] [PubMed]

98. Zhang, L.-L.; Han, L.; Yang, S.-Y.; Meng, X.-M.; Ma, W.-F.; Wang, M. The mechanism of interactions between flavan-3-ols against a-glucosidase and their in vivo antihyperglycemic effects. Bioorganic Chem. 2019, 85, 364-372. [CrossRef]

99. Pitchai, D.; Balasubramanian, K.; Rajalakshmi, M.; Eliza, J.; Selvaraj, J. Insulin mimetic impact of catechin isolated from Cassia fistula on the glucose oxidation and molecular mechanisms of glucose uptake on Streptozotocin-induced diabetic Wistar rats. Phytomedicine 2010, 17, 28-36. [CrossRef]

100. Amalan, V.; Vijayakumar, N.; Indumathi, D.; Ramakrishnan, A. Antidiabetic and antihyperlipidemic activity of p-coumaric acid in diabetic rats, role of pancreatic GLUT 2: In vivo approach. Biomed. Pharmacother. 2016, 84, 230-236. [CrossRef]

101. Matin, A.; Doddareddy, M.R.; Gavande, N.; Nammi, S.; Groundwater, P.W.; Roubin, R.H.; Hibbs, D.E. The discovery of novel isoflavone pan peroxisome proliferator-activated receptor agonists. Bioorg. Med. Chem. 2013, 21, 766-778. [CrossRef]

102. Kang, Y.-J.; Jung, U.J.; Lee, M.-K.; Kim, H.-J.; Jeon, S.-M.; Park, Y.B.; Chung, H.-G.; Baek, N.-I.; Lee, K.-T.; Jeong, T.-S.; et al. Eupatilin, isolated from Artemisia princeps Pampanini, enhances hepatic glucose metabolism and pancreatic $\beta$-cell function in type 2 diabetic mice. Diabetes Res. Clin. Pract. 2008, 82, 25-32. [CrossRef]

103. Kang, Y.-J.; Jung, U.-J.; Jeon, S.-M.; Yeo, J.-Y.; Kim, H.-J.; Kim, D.-J.; Lee, M.-K.; Baek, N.-I.; Chung, H.-G.; Choi, M.-S. Antihyperglycemic and antioxidant properties of jaceosidin, a flavonoid isolated from Artemisia Princeps, in type 2 diabetic mice. Diabetes 2007, 56, pA667. 
104. Chen, J.; Mangelinckx, S.; Ma, L.; Wang, Z.; Li, W.; De Kimpe, N. Caffeoylquinic acid derivatives isolated from the aerial parts of Gynura divaricata and their yeast $\alpha$-glucosidase and PTP1B inhibitory activity. Fitoterapia 2014, 99, 1-6. [CrossRef] [PubMed]

105. Somsak, N.; Peerawit, P.; Chusri, T. Hypoglycemic activity in diabetic rats of stigmasterol and sitosterol-3-O- $\beta$-D-glucopyranoside isolated from Pseuderanthemum palatiferum (Nees) Radlk. leaf extract. J. Med. Plants Res. 2015, 9, 629-635. [CrossRef]

106. Varshney, R.; Varshney, R.; Mishra, R.; Gupta, S.; Sircar, D.; Roy, P. Kaempferol alleviates palmitic acid-induced lipid stores, endoplasmic reticulum stress and pancreatic $\beta$-cell dysfunction through AMPK/mTOR-mediated lipophagy. J. Nutr. Biochem. 2018, 57, 212-227. [CrossRef]

107. Peng, X.; Zhang, G.; Liao, Y.; Gong, D. Inhibitory kinetics and mechanism of kaempferol on $\alpha$-glucosidase. Food Chem. 2016, 190, 207-215. [CrossRef]

108. Jiang, H.; Yamashita, Y.; Nakamura, A.; Croft, K.D.; Ashida, H. Quercetin and its metabolite isorhamnetin promote glucose uptake through different signalling pathways in myotubes. Sci. Rep. 2019, 9, 2690. [CrossRef]

109. Li, H.; Song, F.; Xing, J.; Tsao, R.; Liu, Z.; Liu, S. Screening and structural characterization of $\alpha$-glucosidase inhibitors from hawthorn leaf flavonoids extract by ultrafiltration LC-DAD-MS $\mathrm{n}$ and SORI-CID FTICR MS. J. Am. Soc. Mass Spectrom. 2009, 20, 1496-1503. [CrossRef]

110. Roghani, M.; Fallahi, F.; Moghadami, S. Citrus flavonoid naringenin improves aortic reactivity in streptozotocin-diabetic rats. Indian J. Pharmacol. 2012, 44, 382-386. [CrossRef]

111. Silva, F.S.G.; Oliveira, P.J.; Duarte, M. Oleanolic, ursolic, and betulinic acids as food supplements or pharmaceutical agents for type 2 diabetes: Promise or illusion? J. Agric. Food Chem. 2016, 64, 2991-3008. [CrossRef]

112. Jung, U.J.; Lee, M.-K.; Park, Y.B.; Jeon, S.-M.; Choi, M.-S. Antihyperglycemic and antioxidant properties of caffeic acid in db/db mice. J. Pharmacol. Exp. Ther. 2006, 318, 476-483. [CrossRef]

113. Cremonini, E.; Bettaieb, A.; Haj, F.G.; Fraga, C.G.; Oteiza, P. (-)-Epicatechin improves insulin sensitivity in high fat diet-fed mice. Arch. Biochem. Biophys. 2016, 599, 13-21. [CrossRef] [PubMed]

114. Honda, M.; Hara, Y. Inhibition of rat small intestinal sucrase and $\alpha$-glucosidase activities by tea polyphenols. Biosci. Biotechnol. Biochem. 1993, 57, 123-124. [CrossRef] [PubMed]

115. Mata, R.; Cristians, S.; Escandón-Rivera, S.M.; Juárez-Reyes, K.; Rivero-Cruz, I. Mexican antidiabetic herbs: Valuable sources of inhibitors of $\alpha$-glucosidases. J. Nat. Prod. 2013, 76, 468-483. [CrossRef] [PubMed]

116. De Sousa, E.; Zanatta, L.; Seifriz, I.; Creczynski-Pasa, T.B.; Pizzolatti, M.G.; Szpoganicz, B.; Silva, F.R.M.B. Hypoglycemic effect and antioxidant potential of kaempferol-3,7-o- $(\alpha)$-dirhamnoside from Bauhinia forficate leaves. J. Nat. Prod. 2004, 67, 829-832. [CrossRef] [PubMed]

117. Prasad, C.N.V.; Suma, S.M.; Banerji, A.; Gopalakrishnapillai, A. Kaempferitrin inhibits GLUT4 translocation and glucose uptake in 3T3-L1 adipocytes. Biochem. Biophys. Res. Commun. 2009, 380, 39-43. [CrossRef]

118. Babu, S.; Krishnan, M.; Rajagopal, P.; Periyasamy, V.; Veeraraghavan, V.; Govindan, R.; Jayaraman, S. Beta-sitosterol attenuates insulin resistance in adipose tissue via IRS-1/Akt mediated insulin signaling in high fat diet and sucrose induced type-2 diabetic rats. Eur. J. Pharmacol. 2020, 873, 173004. [CrossRef] [PubMed]

119. Qadan, F.; Verspohl, E.J.; Nahrstedt, A.; Petereit, F.; Matalka, K. Cinchonain Ib isolated from Eriobotrya japonica induces insulin secretion in vitro and in vivo. J. Ethnopharmacol. 2009, 124, 224-227. [CrossRef]

120. Szkudelski, T.; Szkudelska, K. Anti-diabetic effects of resveratrol. Ann. N. Y. Acad. Sci. 2011, 1215, 34-39. [CrossRef]

121. Timmers, S.; De Ligt, M.; Phielix, E.; Van De Weijer, T.; Hansen, J.; Moonen-Kornips, E.; Schaart, G.; Kunz, I.; Hesselink, M.K.C.; Schrauwen-Hinderling, V.B. Resveratrol as add-on therapy in subjects with well-controlled type 2 diabetes: A randomized controlled trial. Diabetes Care 2016, 39, 2211-2217. [CrossRef]

122. Khursheed, R.; Singh, S.K.; Wadhwa, S.; Kapoor, B.; Gulati, M.; Kumar, R.; Ramanunny, A.K.; Awasthi, A.; Dua, K. Treatment strategies against diabetes: Success so far and challenges ahead. Eur. J. Pharmacol. 2019, 862, 172625. [CrossRef]

123. Nenquin, M.; Henquin, J.C. Sulphonylurea receptor-1, sulphonylureas and amplification of insulin secretion by Epac activation in $\beta$ cells. Diabetes Obes. Metab. 2016, 18, 698-701. [CrossRef] [PubMed]

124. Grant, J.S.; Graven, L.J. Progressing from metformin to sulfonylureas or meglitinides. Workplace Health Saf. 2016, 64, 433-439. [CrossRef] [PubMed] 
125. Andersen, E.S.; Deacon, C.F.; Holst, J.J. Do we know the true mechanism of action of the DPP-4 inhibitors? Diabetes Obes. Metab. 2018, 20, 34-41. [CrossRef] [PubMed]

126. Andersen, A.; Lund, A.; Knop, F.K.; Vilsbøll, T. Glucagon-like peptide 1 in health and disease. Nat. Rev. Endocrinol. 2018, 14, 390-403. [CrossRef]

127. Rivero-Cruz, I.; Cristians, S.; Ovalle-Magallanes, B.; Mata, R. Mexican copalchis of the Rubiaceae family: More than a century of pharmacological and chemical investigations. Phytochem. Rev. 2019, 18, 1435-1455. [CrossRef]

128. Wang, B.; Li, N.; Liu, T.; Sun, J.; Wang, X. Synthesis and biological evaluation of novel neoflavonoid derivatives as potential antidiabetic agents. RSC Adv. 2017, 7, 34448-34460. [CrossRef]

129. Yap, A.; Nishiumi, S.; Yoshida, K.-I.; Ashida, H. Rat L6 myotubes as an in vitro model system to study GLUT4-dependent glucose uptake stimulated by inositol derivatives. Cytotechnology 2007, 55, 103-108. [CrossRef]

130. Chen, Y.; Ma, H.; Zhu, D.; Zhao, G.; Wang, L.; Fu, X.; Chen, W. Discovery of novel insulin sensitizers: Promising approaches and targets. PPAR Res. 2017, 2017, 1-13. [CrossRef]

131. Nanjan, M.; Mohammed, M.; Kumar, B.R.P.; Chandrasekar, M. Thiazolidinediones as antidiabetic agents: A critical review. Bioorganic Chem. 2018, 77, 548-567. [CrossRef]

132. Davidson, M.A.; Mattison, D.R.; Azoulay, L.; Krewski, D. Thiazolidinedione drugs in the treatment of type 2 diabetes mellitus: Past, present and future. Crit. Rev. Toxicol. 2017, 48, 52-108. [CrossRef]

133. Guyton, A.C.; Hall, J.E. Textbook of Medical Physiology, 11th ed.; Elsevier: Philadelphia, PA, USA, 2006.

134. DeFronzo, R.A.; Mandarino, L.; Ferrannini, E. Metabolic and Molecular Pathogenesis of Type 2 Diabetes Mellitus. In International Textbook of Diabetes Mellitus; DeFronzo, R.A., Ferrannini, E., Keen, H., Zimet, P., Eds.; Wiley: Hoboken, NJ, USA, 2003.

135. Hunter, R.W.; Hughey, C.C.; Lantier, L.; Sundelin, E.I.O.; Peggie, M.; Zeqiraj, E.; Sicheri, F.; Jessen, N.; Wasserman, D.H.; Sakamoto, K. Metformin reduces liver glucose production by inhibition of fructose-1-6-bisphosphatase. Nat. Med. 2018, 24, 1395-1406. [CrossRef] [PubMed]

136. Liberati, A.; Altman, U.G.; Tetzlaff, J.; Mulrow, C.; Gøtzsche, P.C.; Ioannidis, J.P.A.; Clarke, M.; Devereaux, P.J.; Kleijnen, J.; Moher, D. The PRISMA statement for reporting systematic reviews and meta-analyses of studies that evaluate healthcare interventions: Explanation and elaboration. BMJ 2009, 339, b2700. [CrossRef] [PubMed]

(C) 2020 by the authors. Licensee MDPI, Basel, Switzerland. This article is an open access article distributed under the terms and conditions of the Creative Commons Attribution (CC BY) license (http://creativecommons.org/licenses/by/4.0/). 